\title{
Racial and Ethnic Disparities in Crime and Criminal Justice in the United States
}

\section{Citation}

Sampson, Robert J., and Janet L. Lauritsen. 1997. Racial and ethnic disparities in crime and criminal justice in the United States. Crime and Justice 21: 311-374.

\section{Published Version}

http://dx.doi.org/10.1086/449253

\section{Permanent link}

http://nrs.harvard.edu/urn-3:HUL.InstRepos:3226952

\section{Terms of Use}

This article was downloaded from Harvard University's DASH repository, and is made available under the terms and conditions applicable to Other Posted Material, as set forth at http:// nrs.harvard.edu/urn-3:HUL.InstRepos:dash.current.terms-of-use\#LAA

\section{Share Your Story}

The Harvard community has made this article openly available.

Please share how this access benefits you. Submit a story.

\section{Accessibility}




\section{CHICAgo JOURnals}

Racial and Ethnic Disparities in Crime and Criminal Justice in the United States

Author(s): Robert J. Sampson and Janet L. Lauritsen

Source: Crime and Justice, Vol. 21, Ethnicity, Crime and Immigration: Comparative and Cross

-National Perspectives (1997), pp. 311-374

Published by: The University of Chicago Press

Stable URL: http://www.jstor.org/stable/1147634

Accessed: 01/08/2009 03:02

Your use of the JSTOR archive indicates your acceptance of JSTOR's Terms and Conditions of Use, available at http://www.jstor.org/page/info/about/policies/terms.jsp. JSTOR's Terms and Conditions of Use provides, in part, that unless you have obtained prior permission, you may not download an entire issue of a journal or multiple copies of articles, and you may use content in the JSTOR archive only for your personal, non-commercial use.

Please contact the publisher regarding any further use of this work. Publisher contact information may be obtained at http://www.jstor.org/action/showPublisher?publisherCode=ucpress.

Each copy of any part of a JSTOR transmission must contain the same copyright notice that appears on the screen or printed page of such transmission.

JSTOR is a not-for-profit organization founded in 1995 to build trusted digital archives for scholarship. We work with the scholarly community to preserve their work and the materials they rely upon, and to build a common research platform that promotes the discovery and use of these resources. For more information about JSTOR, please contact support@jstor.org.

The University of Chicago Press is collaborating with JSTOR to digitize, preserve and extend access to Crime and Justice. 


\section{Robert 7. Sampson and Fanet L. Lauritsen}

\section{Racial and Ethnic Disparities in Crime and Criminal Justice in the United States}

\section{A B S T R A C T}

Although racial discrimination emerges some of the time at some stages of criminal justice processing-such as juvenile justice-there is little evidence that racial disparities result from systematic, overt bias. Discrimination appears to be indirect, stemming from the amplification of initial disadvantages over time, along with the social construction of "moral panics" and associated political responses. The "drug war" of the 1980s and 1990s exacerbated the disproportionate representation of blacks in state and federal prisons. Race and ethnic disparities in violent offending and victimization are pronounced and long-standing. Blacks, and to a lesser extent Hispanics, suffer much higher rates of robbery and homicide victimization than do whites. Homicide is the leading cause of death among young black males and females. These differences result in part from social forces that ecologically concentrate race with poverty and other social dislocations. Useful research would emphasize multilevel (contextual) designs, the idea of "cumulative disadvantage" over the life course, the need for multiracial conceptualizations, and comparative, cross-national designs.

Research on race and crime has become a growth industry in the United States. For much of this century, studies have poured forth on racial differences in delinquency, crime, victimization, and, most of all, criminal justice processing. To take but one example, racial differences in sentencing have captured the attention of numerous journal articles,

Robert J. Sampson is professor of sociology at the University of Chicago and research fellow at the American Bar Foundation. Janet L. Lauritsen is associate professor of criminology and criminal justice at the University of Missouri at St. Louis. We thank John Laub, Michael Tonry, and participants in the 1994 Race, Ethnicity, and Criminal Justice conference in Oxford for helpful comments on an earlier draft.

(c) 1997 by The University of Chicago. All rights reserved.

0192-3234/97/0021-0005\$01.00 
books, meta-analyses, and a panel of the National Academy of Sciences (among others, see reviews in Kleck 1981; Hagan and Bumiller 1983; Petersilia 1985).

The volume of research has not gone hand in hand with dispassionate scholarly debate. The topic of race and crime still rankles, fueling ideologically charged discussions over competing schools of thought such as discrimination versus differential involvement, cultures of violence versus structural inequality, and empiricism versus critical theory. Some argue that bringing empirical data to bear on the race and crime question is itself evidence of racism (MacLean and Milovanovic 1990). It is thus not surprising that, despite the abundance of empirical data, many criminologists are loathe to speak openly on race and crime for fear of being misunderstood or labeled a racist. This situation is not unique, for until recently scholars of urban poverty also consciously avoided forthright discussion of race and social problems in the inner city lest they be accused of blaming the victim (see Wilson 1987, pp. 3-19; Sampson and Wilson 1995).

What, then, does one make of the charge to assess the current state of knowledge on racial-ethnic disparities and discrimination in the justice systems of the United States and of the sources of knowledge from which such conclusions can be drawn? The sheer volume of research makes a review of empirical studies impossible in one essay, and the political climate suggests a no-win substantive outcome as well. In addition, many important questions remain unanswered either because we lack the necessary data or because results are conflicting across alternative forms of measurement. Recognizing these perils, we nonetheless tackle the topic of race, ethnicity, and crime in the United States by focusing on four general questions: What are the key empirical findings on race, ethnicity, and crime? What are the most promising theoretical explanations? What are the major limitations of both research and theory? and Where do we go from here?

Rather than try to review all individual studies, we close in on the "big picture" - that is, the one painted by robust findings that hold up across disparate investigators, forms of data collection, and analytical methods. But empirical generalizations only take us so far (we have yet to hear data speak), so the second question becomes crucial-what theoretical and substantive interpretations can we place on the empirical data? Of course, both the answers to this question and the empirical backdrop of data are subject to numerous pitfalls, and hence question three prompts an inquiry into the limitations of extant knowledge. 
Consideration of limitations leads naturally to the final question of future research designs. In probing this issue, we focus on how knowledge might be advanced by using a comparative, international perspective with collaborative research designs.

Our essay addresses these questions in the following way. We start with a discussion of general contextual issues relevant to the United States. For background purposes, Section I describes the racial and ethnic makeup of the U.S. population and the American criminal justice system. Sections II-VI subdivide the empirical morass of U.S. data into several interrelated domains. Section II discusses race, ethnicity, and criminal victimization (who becomes victimized by crime?), whereas Section III overviews the literature on race, ethnicity, and criminal offending (who commits criminal acts?). The findings presented in these two sections represent the dominant tradition in criminology, which seeks to distinguish individual offenders from nonoffenders and victims from nonvictims. Section IV discusses the community structure of race, ethnicity, and crime in the United States, namely, what are the characteristics of communities that contribute to rates of crime for different race and ethnic groups? The findings from the community literature are compared with evidence on individual differences in criminal involvement, and critical problems in interpretation are discussed. ${ }^{1}$ Section $\mathrm{V}$ summarizes the findings on racial disparities in the U.S. criminal justice system (e.g., who gets convicted and imprisoned?), and Section VI reviews the various approaches for understanding differential treatment. Finally, Section VII presents our interpretations of the literature on race, crime, and criminal justice and discusses what we believe are the important implications for future research.

Before we begin, it is important to qualify our use of the terms "race" and "ethnicity." In the United States, the term "race" traditionally refers to skin pigmentation or color, whereas ethnicity refers to the countries from which a person's ancestors can be traced. For various historical and social reasons, definitions of race in the United States have referred mainly to categories that are allegedly mutually exclusive- $(a)$ white, $(b)$ black, $(c)$ American Indian, Eskimo, or Aleut, and (d) Asian or Pacific Islander. The American conception of eth-

${ }^{1}$ Our review of the empirical evidence on racial differences in victimization and offending, and our theoretical arguments regarding communities, race, and crime, are drawn in large part from two previous papers-Sampson and Lauritsen (1994) and Sampson and Wilson (1995). 
nicity differs from that of race in that it is usually reported by subjects themselves (as opposed to visual identification), and it may consist of as many categories as one believes necessary to indicate his or her heritage. Clearly, however, there are ongoing scholarly and political debates that challenge the definitions and usefulness of these terms in U.S. society. For example, it has been argued that the American conception of race is arbitrary insofar as there is no single set of traits that satisfactorily distinguish one group from another. Biological research reminds us that race definitions are socially constructed and reflect the concerns and preoccupations of a particular society (e.g., Hawkins 1995; Marks 1995). Simple classification attempts rooted in biological analogies are also invalidated because many individuals are of mixed races. Furthermore, we sympathize with those who argue that by highlighting race differences in crime and criminal justice sanctioning, such work has the potential to exacerbate problems of institutional racism and stereotyping in the United States.

Yet to acknowledge these points does not undermine the salience of race or ethnicity, however socially constructed, in a given society. There are profound race and ethnic differences in the representation of citizens in the U.S. criminal justice system. It seems to us that knowledge about the origins and consequences of these discrepancies is preferable to ignorance-even as we acknowledge that observed differences between groups are not due to inherent differences in physical traits. We would add that while definitions and records of race and ethnicity differ across countries, the social conception of race has validity and reliability within the United States. We are less certain of the validity of the term "ethnicity" since social agreement as to whether someone is, for example, Hispanic or of some other ethnic heritage is likely to be much lower. For our purposes, then, the definition of race imposed by administrative and political structures is an important subject of study in its own right, but it should not be a significant source of error when making cross-group comparisons. The interpretation of ethnic differences (much less available in the data) requires more caution. Other data limitations, not relevant to definitional issues, are discussed when appropriate.

\section{The U.S. Context}

The Census Bureau currently defines race in five broad categories"white," "black," “American Indian, Eskimo, or Aleut," "Asian or 
Pacific Islander" (further subdivided into ten groups), and "other."' Recent data on ethnicity usually focus on whether persons are of "Hispanic" origin. The term Hispanic is meant to define persons of Spanish-speaking origin who may identify themselves as any one of the racial groups. There is great diversity in how Hispanics define themselves racially, and there are perhaps even greater cultural differences between, say, Puerto Ricans and Cubans, as there are between racial groups. Not sharing a common culture, the myriad groups classified as Hispanic thus fail to meet the criteria we typically think of as constituting an ethnic group. For these and other reasons, the construct of Hispanic has been criticized as a political definition that has little meaning (e.g., Mann 1993, pp. 8-12), with many preferring the label "Latino" instead. Similar arguments have been made about the meaning of race categories, namely, that there is more within-group variation (in terms of traditional cultural experiences) than there are differences between race groups.

Though few still hold to the notion of the United States as a "melting pot" of racial and ethnic cultures, there is little doubt that the pot is becoming increasingly diverse. Table 1 presents census data on the resident population of the United States and changes from 1980 to 1990 by race and Hispanic origin. Whites made up 80 percent of the approximately 250,000,000 residents of the U.S. population in 1990. This represents a decline from 83 percent in 1980. Blacks represent 12 percent of the 1990 population, up modestly from 1980. Native American Indians comprise a very small portion of the population-less than 1 percent. However, each of the Chinese, Asian Indian, Korean, and Vietnamese populations increased more than 100 percent over the decade.

The other striking feature of table 1 is the sharp growth in the number of Hispanic Americans-53 percent-to the point where they now make up almost 10 percent of the U.S. population. If the growth rate of more than 50 percent continues into the next century as demographic predictions suggest, Hispanic Americans will represent the

\footnotetext{
${ }^{2}$ The U.S. Bureau of the Census is likely to change how it measures "race" and "ethnicity" before implementation of the next decennial census. Race and ethnicity are selfidentified in the census questionnaires, and many have argued that existing categories do not capture many persons' sense of identity. The most pressing issues involve the classification of multiracial persons and individuals who consider themselves neither "white" nor "black." Whatever the decision of the Bureau of the Census, it will affect the kinds of questions researchers ask and the politics of race in America (e.g., eligibility for federal aid to minorities, minority redistricting for elections).
} 


\section{TABLE 1}

Resident Population, by Race and Hispanic Origin: 1980 and 1990 (as of April 1)

\begin{tabular}{|c|c|c|c|c|}
\hline \multirow[b]{3}{*}{ Race and Hispanic Origin } & \multirow{2}{*}{\multicolumn{2}{|c|}{$N$ (in Thousands) }} & \multicolumn{2}{|c|}{$\begin{array}{l}\text { Change, } \\
1980-90\end{array}$} \\
\hline & & & \multirow{2}{*}{$\begin{array}{c}N \text { (in } \\
\text { Thousands) }\end{array}$} & \multirow[b]{2}{*}{ Percent } \\
\hline & 1980 & 1990 & & \\
\hline All persons & 226,546 & 248,710 & 22,164 & 9.8 \\
\hline \multicolumn{5}{|l|}{ Race: } \\
\hline White & 188,372 & 199,686 & 11,314 & 6.0 \\
\hline Black & 26,495 & 29,986 & 3,491 & 13.2 \\
\hline American Indian, Eskimo, or Aleut: & 1,420 & 1,959 & 539 & 37.9 \\
\hline American Indian & 1,364 & 1,878 & 514 & 37.7 \\
\hline Eskimo & 42 & 57 & 15 & 35.6 \\
\hline Aleut & 14 & 24 & 10 & 67.5 \\
\hline Asian or Pacific Islander: & 3,500 & 7,274 & 3,773 & 107.8 \\
\hline Chinese & 806 & 1,645 & 839 & 104.1 \\
\hline Filipino & 775 & 1,407 & 632 & 81.6 \\
\hline Japanese & 701 & 848 & 147 & 20.9 \\
\hline Asian Indian & 362 & 815 & 454 & 125.6 \\
\hline Korean & 355 & 799 & 444 & 125.3 \\
\hline Vietnamese & 262 & 615 & 353 & 134.8 \\
\hline Hawaiian & 167 & 211 & 44 & 26.5 \\
\hline Samoan & 42 & 63 & 21 & 50.1 \\
\hline Guamanian & 32 & 49 & 17 & 53.4 \\
\hline Other Asian or Pacific Islander & N.A. & 822 & N.A. & N.A. \\
\hline Other race & 6,758 & 9,805 & 3,047 & 45.1 \\
\hline \multicolumn{5}{|l|}{ Hispanic origin: } \\
\hline Of Hispanic origin: & 14,609 & 22,354 & 7,745 & 53.0 \\
\hline Mexican & 8,740 & 13,496 & 4,755 & 54.4 \\
\hline Puerto Rican & 2,014 & 2,728 & 714 & 35.4 \\
\hline Cuban & 803 & 1,044 & 241 & 30.0 \\
\hline Other Hispanic & 3,051 & 5,086 & 2,035 & 68.7 \\
\hline Not of Hispanic origin & 211,937 & 228,356 & 14,419 & 6.8 \\
\hline
\end{tabular}

Source.-U.S. Bureau of the Census (1993), p. 18.

Note. -N.A. $=$ not available. $Z<0.05 \%$.

largest "minority" group. Overall, if the data are reclassified to take account of both race and ethnic identification, the United States is dominated by three race and ethnic groups-non-Hispanic whites (75 percent), non-Hispanic blacks (12 percent), and Hispanics (9 percent). In urban areas where crime rates tend to be highest, non-Hispanic whites no longer represent the majority population in many of the nation's largest cities (e.g., Los Angeles, Chicago, Detroit). 
Despite the changing racial and ethnic diversity of U.S. society, in this essay we focus mainly on "black" and "white" comparisons. The reason stems primarily from a lack of data on crime that consistently classifies information for Hispanic and non-Hispanics, and for groups such as Asians and Native Americans. Where available and appropriate, data reflecting these latter classifications is presented (e.g., arrest statistics). Moreover, most analytical work on disparity and discrimination in crime and sanctioning has focused on comparisons between whites and blacks.

Unfortunately, the types of crime covered in this essay's explication of race and ethnic disparities are not fully representative of the landscape of criminal behavior in the United States. For many "whitecollar" and "organized" crimes, sound data are hard to come by. ${ }^{3}$ Perhaps more crucially, the data that do exist are rarely presented to permit systematic study of race and ethnic variations. Although there is excellent reason to believe that whites are overrepresented in "crimes of the suite," an analysis of this phenomenon is beyond the scope of current efforts. However, a large body of research in the United States on racial and ethnic disparities focuses on "street" or "index" crimesespecially violence (e.g., murder, rape, robbery, assault) and property crime (e.g., larceny, motor vehicle theft, burglary). Race and ethnic comparisons are usually possible for these offenses, and hence we focus disproportionately on crimes against persons and property.

Of these two general crime types, we give more coverage to violence. As seen below, race and ethnic disparities in both criminal offending and criminal victimization tend to be greatest among violent crimes. With homicide mortality rates now at least eight times higher among young black males than young white males (National Center for Health Statistics 1995, table 6), a sense of public urgency has also emerged regarding a crisis of violence in the black community (DiIulio 1994; Sampson and Wilson 1995). Understanding racial disparities in urban violence is thus a major priority for criminal justice in the United States, and our review reflects this concern. We recognize that by focusing our attention on violence, we are in danger of overemphasizing the importance of race or ethnicity in offending and victimization and underemphasizing its influence on criminal justice decision making. We attempt to compensate for this possible bias by includ-

\footnotetext{
${ }^{3}$ Corporate crimes are excluded because the "offender" is an institution rather than an individual. In theory, however, one could characterize the race and ethnic composition of corporate decision makers.
} 
ing relevant information on other crime types-particularly drug offending and drug sanctioning, which have attracted much recent concern in the United States (see Blumstein 1993a; Tonry 1995).

A further complication is that the justice system in the United States is decidedly complex, making the task of tracking racial disparities even more difficult. It is probably a misnomer to speak of a "system" of criminal justice because some 90 percent of all crimes are prosecuted at state and local levels. With fifty states and separate procedures for juveniles and adults, the United States is characterized by wide variation in local practices, laws, and criminal justice operations. Still, there is a common thread that ties together the way that most criminal cases are processed (see U.S. Department of Justice 1988, p. 56). The bulk of previous research has centered on key decision points in the processing of adults, especially arrest, bail (pretrial release), charging, plea bargaining, conviction, sentencing (e.g., to probation, imprisonment), and postcorrectional release (e.g., parole). Like the social organization of the criminal justice system, data reflecting this process are similarly complex. They run the gamut from local records (e.g., arrest statistics for a city precinct) to national figures published by the U.S. government. Because of this variation, data sources are described below in tandem with the phenomenon under consideration.

\section{Race-Ethnicity and Criminal Victimization}

What are the risks of victimization to individuals of different racial and ethnic groups? Are these differences stable over recent time periods? Answers to these types of questions have been obtained largely through analyses of National Crime Victimization Survey (NCVS) data. The NCVS (previously known as the National Crime Survey [NCS]) is an ongoing survey conducted by the Bureau of Justice Statistics, designed to measure the extent of personal and household victimization in the United States. Interviews are conducted at six-month intervals with all persons twelve years of age or older living in a sampled household. As many as 150,000 persons in 80,000 households are interviewed on a biannual basis. The major advantage of the NCVS is the ability to estimate victimizations that may be incorrectly reflected in official police data (e.g., because of nonreporting of incidents or arrest bias). The NCVS therefore constitutes the best available data source on the risk of victimization for various population subgroups living in the United States. The exception, naturally, is for homicide, where most estimates 
are based on vital statistics (e.g., Fingerhut and Kleinman 1990) and the FBI's supplemental homicide reports which provide a racial classification of homicide victims.

Victimization research over the past twenty years has consistently shown that the overall risk of experiencing personal violence (i.e., homicide, rape, robbery, or assault) is much lower than the risk of household victimization (U.S. Department of Justice 1994a). For example, the combined risk of suffering a violent victimization by either rape, robbery, or assault in 1992 was estimated at approximately 1 in 31, while the risk of household burglary was nearly 1 in 6 . However, the major finding for our purposes is that the distribution of victimization varies systematically across different subgroups. In terms of race, both the NCVS and official statistics confirm that blacks are disproportionately the victims of violent crimes (U.S. Department of Justice 1993a, 1994b). Differences in homicide risk are the most pronounced. According to the U.S. Department of Justice, in 1992 blacks were nearly seven times more likely than whites to become victims of homicide $(1993 a)$. Similarly, data derived from death certificates (rather than crime reports) and that adjust for differences in the age composition of the two populations show that the 1992 rate of homicide for the black population was 6.5 times that for the white population (National Center for Health Statistics 1995).

Estimates of homicide risk over the life span further underscore racial disparities. By 1990, black women and black men were, respectively, four and six times more likely than white women and white men to be murdered in their lifetime (Reiss and Roth 1993, p. 63). The leading cause of death among black males and black females ages fifteen to twenty-four is homicide (National Center for Health Statistics 1995). These differentials help explain estimates that a resident of rural Bangladesh has a greater chance of surviving to age forty than does a black male in Harlem (McCord and Freeman 1990).

Estimates of lifetime homicide risk for American Indians, blacks, and whites are presented in Reiss and Roth (1993, pp. 62-63). The lifetime risk for black males is 4.16 per 100 , followed by Native Indian males (1.75), black females (1.02), white males (.62), Native Indian females (.46), and white females (.26). Thus Native Indian males' risk falls approximately halfway between that of black and white males. Reiss and Roth also note that less than one-fourth of Americans' lifetime risk for homicide is incurred before the twenty-fifth birthday. Consequently, 

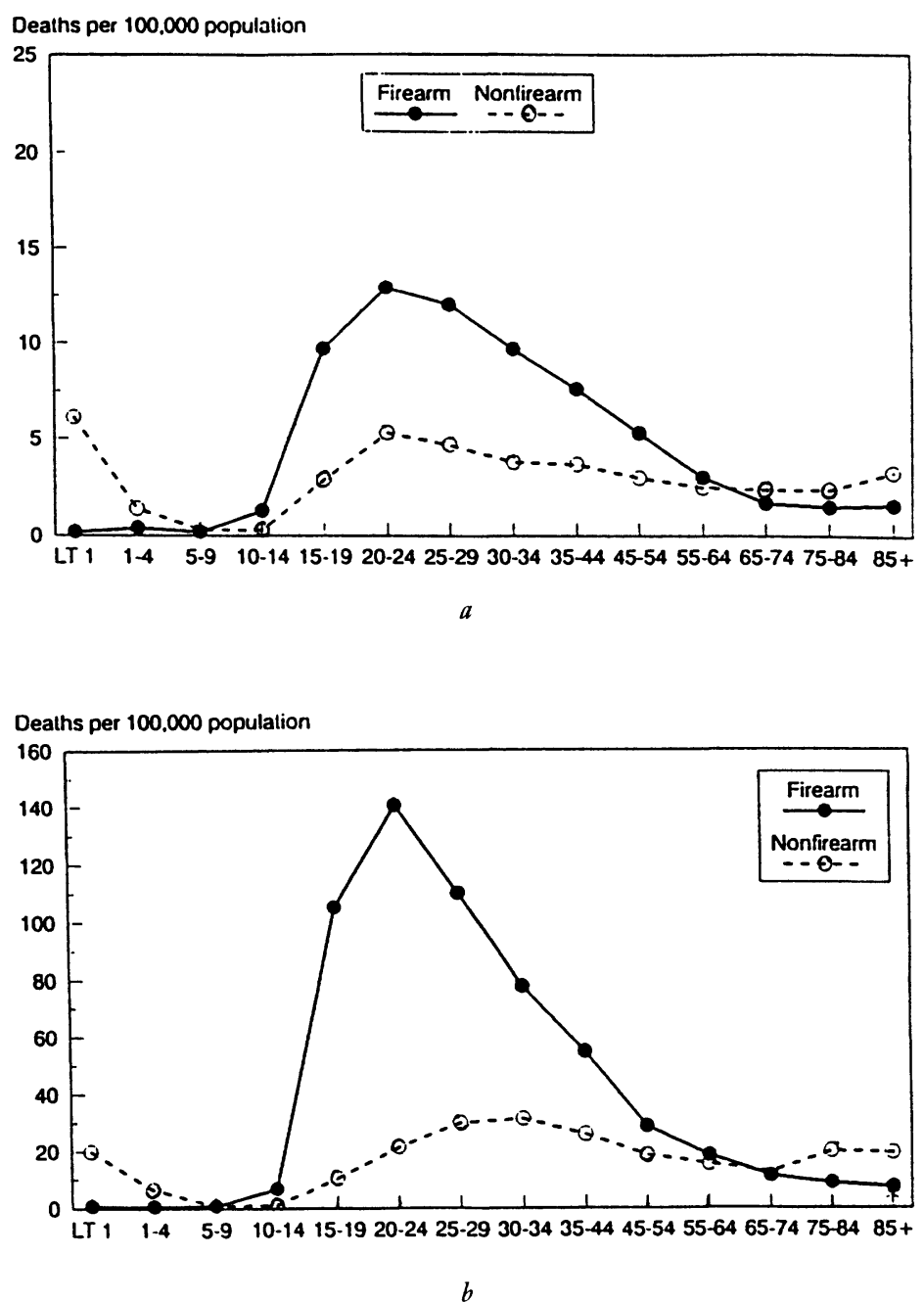

FIg. 1.-Homicide among males by firearm status in the United States. $a$, Among white males. $b$, Among black males. Source: Fingerhut (1993), pp. 16-17.

the very high homicide rates among young black males in particular must be considered in conjunction with the higher homicide rates of black males at all ages.

Racial disparities for gun-related homicide victimization are particularly striking. Figure 1 displays the age-specific 1990 U.S. death rate by firearms for white males and black males according to mortality reports from vital statistics (Fingerhut 1993). Note that the peak death 
rate for young black males (140 per 100,000$)$ is more than ten times greater than the peak death rate for young white males (twelve per $100,000)$. Given the nature of death reports, these differentials in victimization cannot reasonably be attributed to bias in official reaction by the criminal justice system.

As with homicide, blacks report greater levels of robbery victimization than do whites (U.S. Department of Justice 1994a). Over the past twenty years, blacks' risk of robbery has been between two and three times greater than that of whites. While the risk of robbery among whites has slightly declined over the last two decades, the risk among blacks fluctuates more from year to year and shows no clear evidence of decline.

Unlike homicide and robbery, rates of assault victimization for blacks and whites have not differed consistently over the last twenty years, although the majority of assault victimizations reported by blacks tend to be incidents of aggravated assault, whereas simple assaults predominate among whites (U.S. Department of Justice 1994a). The lack of race differences in assaults overall may be the result of differences in reporting. Specifically, it has been hypothesized that blacks may underreport less serious forms of assault and that whites may overreport minor assaults (Skogan 1981; Gottfredson 1986).

Race differentials in victimization risk decline significantly for personal theft (larceny with or without contact) and crimes against property. The personal theft victimization rate is very similar, at fifty-nine per 1,000 for blacks and sixty per 1,000 for whites (U.S. Department of Justice 1994b). However, rates of household victimization (burglary, larceny, and motor vehicle theft) are consistently higher for blacks than for whites. For example, the burglary victimization rate per 1,000 households is sixty-eight for blacks and forty-six for whites (U.S. Department of Justice 1994b). Compared over time, trends in property victimization reveal similar patterns by race. Since about 1980 , both whites and blacks have experienced general declines in personal theft and household victimization.

For violence, however, both rate and trend differences by race are substantial. Beginning about 1990, reported rates of violence among blacks increased to their highest level ever recorded in the NCVS. This trend parallels the trajectory of homicides measured by death records-increases in homicide rates since the mid- to late 1980s in the United States have been racially selective. For example, while white rates remained relatively stable, the firearms death rate among young 
black males more than doubled from 1984 to 1988 alone (see Fingerhut et al. 1991). ${ }^{4}$

In short, the available race-specific data on victimization suggest a fairly straightforward pattern. Blacks suffer much higher rates of personal violence and homicide victimization than do whites. Racial differences are reduced considerably in magnitude when it comes to household crimes and especially personal theft victimizations. And while overall victimization trends are similar for blacks and whites, robbery and homicide are the two notable exceptions. Recent trends for these two violent crimes show greater increases for blacks than whites.

The NCVS provides only limited information on ethnic differences in victimization risk, restricted mainly to Hispanic versus non-Hispanic comparisons. According to the NCVS, Hispanics experience higher rates of violent and household victimization than nonHispanics (39.6 vs. 35.3 , and 265.6 vs. 204.5, respectively). Conversely, non-Hispanics report higher rates of personal theft (80.3) than Hispanics (74.9) (U.S. Department of Justice 1990). Government vital statistics on mortality provide another source of comparison, as they report the cause of death for Hispanics and non-Hispanic whites. As is true for blacks, the leading cause of death among Hispanics aged 1524 is homicide (National Center for Health Statistics 1995).

Recall that in the United States race and ethnicity are not mutually exclusive categories. Because Hispanics may be designated as either black or white (or "other"), compositional effects may account for the higher NCVS victimization rates of Hispanics than of non-Hispanics. Since NCVS summary reports do not present differences between non-Hispanic whites, non-Hispanic blacks, and Hispanics, it is difficult to know precisely to what degree these subgroups differ in their risks of victimization. Similarly, vital statistics do not provide homicide rates for Hispanics because population estimates by race-ethnicity remain uncertain.

The primary explanation of the race-victimization connection in violence stems from "lifestyle" (Hindelang, Gottfredson, and Garofalo 1978; Garofalo 1987) and "routine activity" (Cohen and Felson 1979) theories of victimization. The essential proposition of lifestyle-routine activity theories is that the convergence in time and space of suitable targets and the absence of capable guardians leads to increases in crime independent of the structural and cultural conditions that may moti-

${ }^{4}$ The most recent data indicate that the overall age-adjusted firearm death rates declined slightly between 1991 and 1992 (National Center for Health Statistics 1995, table 19). 
vate individuals to engage in crime (e.g., poverty, unemployment, subcultural values). Derived from this general proposition, the "principle of homogamy" in lifestyle theory states that persons are more likely to be victimized when they disproportionately associate with, or come into contact with, members of demographic groups that contain a disproportionate share of offenders (Hindelang, Gottfredson, and Garofalo 1978, pp. 256-57).

According to this explanation, blacks suffer a higher risk of violent victimization than do whites because they are more likely to associate with other blacks who are themselves disproportionately involved in violence. In other words, race-shaped lifestyle factors such as friendship patterns and leisure activities account for higher levels of risk. Similarly, the "proximity" hypothesis posits that ecological propinquity to the residences of high-rate offender groups will increase one's risk of victimization. The theoretical implication here is that blacks are segregated from whites and live in closer proximity to other blacks who commit crimes at higher rates than whites. As discussed below, the veracity of the differential offending claim has been challenged; however, the key point is that homogamy of personal associations and proximity to offender groups are the leading hypotheses for the race differentials in victimization risk.

The limitations of lifestyle-routine activities theory and research have been discussed at length elsewhere (for overviews, see Gottfredson 1986; Garofalo 1987; Meier and Miethe 1993; Sampson and Lauritsen 1994). The most common criticism of empirical research has been the inadequate measurement of explanatory variables-direct measures of lifestyle activities and proximity to offender populations are not usually included in models containing social and demographic characteristics. In particular, most research on race differences in risk has not been able to distinguish between individual-level interpretations (such as lifestyle and friendship choices) and contextual explanations (such as proximity to offender groups resulting from housing segregation patterns). Clearly, this is an important issue to resolve.

Subcultural explanations have also been used to explain higher rates of victimization, especially violence, among various subgroups (e.g., Wolfgang 1958; Wolfgang and Ferracuti 1967; Singer 1981). The subculture of violence thesis argues that certain subgroups share norms conducive to the use of violence for resolving disputes, thereby generating subgroup differences in victimization. However, this hypothesis has not been empirically validated with respect to race. As discussed more below, key methodological difficulties need to be resolved before 
it can be determined whether differences in normative contexts account for racial differences in violent victimization (see e.g., Kornhauser 1978; Hawley and Messner 1989).

\section{Race-Ethnicity and Criminal Offending}

Prior research on the correlates of criminal offending has extensively reviewed the methodological issues that limit the validity of findings (see e.g., Hindelang 1978; Hindelang, Hirschi, and Weis 1979; Elliott and Ageton 1980), and therefore we mention only a few of these qualifications here. A primary concern is the source of data on offendingwhether the findings are based on official, self-report, or victimization data. Findings based on official data such as arrest statistics published by the FBI's Uniform Crime Reports (UCR) are limited to the extent that apprehended offenders differ in some way from nonapprehended offenders (e.g., because of racial bias). They are also limited in that persons who are arrested more than once in any year are overrepresented in arrest statistics. Findings based on self-report surveys may be limited by either the respondents' intentional or unintentional errors in reporting or by sampling restrictions (e.g., an almost exclusive focus on juveniles or males, or on minor offenses).

Although NCVS victimization data provide information on the perceived race of offenders, estimates are available only for those incidents involving a single or lone offender, and where there is face-to-face contact between the offender and victim. ${ }^{5}$ Thus this restriction excludes race-specific data on crimes committed by two or more offenders, or by groups (such as gangs). It is also the case that victims of personal crimes have been found to underreport certain types of incidents, especially those involving victimizations by family members and acquaintances (Hindelang 1978). These sources of error are all relevant to inferences about race and crime. Consequently, we emphasize convergent findings across various data sources.

\section{A. Arrest Data}

Because nationwide arrest reports are available by race but not by ethnicity, we focus on the most recent race-specific arrest data by of-

\footnotetext{
${ }^{5}$ The NCVS distinguishes between "lone"-offender and "multiple"-offender incidents. Multiple-offender incidents are crimes involving more than one offender per incident. Approximately three-fourths of violent crimes in the United States are committed by lone offenders (see Reiss and Roth 1993, p. 75).
} 
fense type. Presented in table 2, these 1993 data suggest that race is related to criminal offending (see also Maguire and Pastore 1995, table 4.11). Although whites are arrested for the majority of all crimes (approximately 67 percent), blacks and American Indians are most likely to be overrepresented in arrests reported in the UCR. For example, in 1993 blacks comprised 31 percent of total arrests yet constituted 12 percent of the population, and American Indians comprised 1.1 percent of total arrests while constituting .8 percent of the population. Asians, however, appear to be underrepresented in arrest statistics. Note that Asians account for 1.0 percent of all arrests, yet make up 2.9 percent of the population.

The relationship between race and offending is not the same for all crime types; there are certain offenses for which each is overrepresented. For instance, whites are disproportionately arrested for driving while intoxicated, and Asians are over-represented in arrests for illegal gambling. Blacks are consistently more likely to be arrested for crimes of violence (Hindelang 1978; Elliott and Ageton 1980; Bridges and Weis 1989; U.S. Department of Justice 1993b). In 1993, blacks accounted for 45 percent and 50 percent of adult and youth arrestees, respectively, for murder, rape, robbery, and aggravated assault (Maguire and Pastore 1995, pp. 389-90). The crime in which blacks are most overrepresented is robbery (for a fascinating albeit controversial discussion, see Katz 1988), comprising 62 percent of arrestees in 1993. In general, blacks are approximately six times more likely to be arrested for violent crimes than are whites (U.S. Department of Justice 1993b).

Overall trends in index-crime arrest rates for the last twenty-five years show a fluctuating pattern, peaking in the early 1990s for adults and in the mid-1970s and early 1990s for juveniles (U.S. Department of Justice 1993b). ${ }^{6}$ When race-specific trends in these crimes are compared, black and white differences in rates of offending have decreased somewhat over time. For example, in 1965, black juveniles' and adults' arrest rates were 3.1 and 5.7 times that of white juveniles and adults. By 1992, black-white differences in index crime arrest rates had dropped to 2.3 and 4.9 (U.S. Department of Justice 1993b). With respect to violence, murder arrest rates for juveniles also increased in a

\footnotetext{
${ }^{6}$ Index offenses include murder, rape, robbery, aggravated assault, burglary, larceny theft, motor vehicle theft, and arson. However, arson has only recently been added to the classification.
} 
TABLE 2

Breakdown by Offense Charged, Age Group, and Race, United States, 1993 (10,509 Agencies; 1993 Estimated Population $=213,093,000)$

\begin{tabular}{|c|c|c|c|c|}
\hline \multirow[b]{2}{*}{ Offense Charged } & \multicolumn{4}{|c|}{ Percent } \\
\hline & White & Black & $\begin{array}{c}\text { American } \\
\text { Indian or } \\
\text { Alaskan } \\
\text { Native }\end{array}$ & $\begin{array}{l}\text { Asian or } \\
\text { Pacific } \\
\text { Islander }\end{array}$ \\
\hline Total & 66.9 & 31.1 & 1.1 & 1.0 \\
\hline $\begin{array}{l}\text { Murder and nonnegligent man- } \\
\text { slaughter }\end{array}$ & 40.7 & 57.6 & .6 & 1.1 \\
\hline Forcible rape & 56.9 & 41.3 & 1.0 & .8 \\
\hline Robbery & 36.5 & 62.1 & .4 & 1.0 \\
\hline Aggravated assault & 58.4 & 39.8 & .9 & 1.0 \\
\hline Burglary & 67.2 & 30.9 & .9 & 1.0 \\
\hline Larceny theft & 64.6 & 33.0 & 1.0 & 1.4 \\
\hline Motor vehicle theft & 57.1 & 40.3 & .9 & 1.7 \\
\hline Arson & 74.6 & 23.5 & .9 & .9 \\
\hline Violent crime & 52.6 & 45.7 & .8 & 1.0 \\
\hline Property crime & 64.4 & 33.2 & 1.0 & 1.4 \\
\hline Total crime index & 61.3 & 36.5 & .9 & 1.3 \\
\hline Other assaults & 62.9 & 34.9 & 1.2 & 1.0 \\
\hline Forgery and counterfeiting & 63.0 & 35.4 & .6 & 1.0 \\
\hline Fraud & 62.3 & 36.6 & .5 & .7 \\
\hline Embezzlement & 67.4 & 31.0 & .4 & 1.2 \\
\hline $\begin{array}{l}\text { Stolen property; buying, receiving, } \\
\text { possessing }\end{array}$ & 56.1 & 42.3 & .6 & 1.1 \\
\hline Vandalism & 74.8 & 22.9 & 1.1 & 1.2 \\
\hline Weapons; carrying, possessing, etc. & 55.4 & 43.0 & .5 & 1.1 \\
\hline Prostitution and commercialized vice & 62.0 & 35.9 & .6 & 1.5 \\
\hline Sex offenses (except forcible rape & & & & \\
\hline and prostitution) & 77.0 & 20.9 & 1.0 & 1.1 \\
\hline Drug abuse violations & 59.8 & 39.3 & .4 & .5 \\
\hline Gambling & 48.2 & 46.9 & .4 & 4.6 \\
\hline Offenses against family and children & 65.6 & 31.2 & 1.3 & 2.0 \\
\hline Driving under the influence & 87.2 & 10.6 & 1.3 & .9 \\
\hline Liquor laws & 84.5 & 12.6 & 2.3 & .6 \\
\hline Drunkenness & 79.7 & 17.8 & 2.1 & .3 \\
\hline Disorderly conduct & 64.6 & 33.6 & 1.3 & .5 \\
\hline Vagrancy & 56.6 & 41.2 & 1.9 & .4 \\
\hline All other offenses (except traffic) & 62.6 & 35.5 & 1.0 & .9 \\
\hline Suspicion & 46.9 & 52.0 & .6 & .5 \\
\hline Curfew and loitering law violations & 78.8 & 18.1 & 1.1 & 2.0 \\
\hline Runaways & 78.1 & 17.2 & 1.3 & 3.4 \\
\hline
\end{tabular}

Source.-Maguire and Pastore (1995), p. 388.

Note.-Percents sum to 100.0 for each row. 
similar pattern for both blacks and whites in the period 1985-90 (Blumstein 1995, p. 8).

An important exception to these time trends is drug-related arrests. From 1965 through the early 1980s, blacks were approximately twice as likely as whites to be arrested for drug-related offenses (Blumstein 1993a; Tonry 1995). Following the federal government's initiation of the "war on drugs," black arrest rates skyrocketed, while white arrest rates increased only slightly. By the end of the 1980s, blacks were more than five times more likely than whites to be arrested for drug-related offenses. It is highly unlikely that these race differences represent general substance use patterns since drug arrests grew at a time when national self-report data showed that drug use was declining among both blacks and whites. Rather, these differences reflect the government's targeting and enforcement of specific types of drug use and trafficking (Blumstein 1993a; Tonry 1995).

\section{B. Victimization-Based Estimates}

The data presented thus far focus on "offending" as measured by official statistics on arrests. The obvious critique, long voiced in U.S. criminology, is that police decisions to arrest are biased. According to conflict theory, the police believe that blacks-especially low-income blacks-commit more crimes and therefore more often take action to arrest them. The general stereotype of blacks as "disreputable" and "dangerous" (Irwin 1985) thus leads the police to watch and arrest minorities more frequently than warranted based on actual criminal behavior (for further elaboration, see Sampson 1986).

In an important investigation, Hindelang (1978) disentangled the extent to which black overrepresentation in official violent crime data was explained by differential involvement or by differential selection into the criminal justice system via arrests by police. In comparing the distribution of arrestees by race from the 1974 UCR to the distribution of perceived race of offenders derived from the $1974 \mathrm{NCS},{ }^{7}$ he found some evidence for the differential selection hypothesis with respect to assault and rape. Overall, however, reports by victims suggest that most of the race difference found in arrest rates for violence is explained by greater black involvement in personal crimes, especially robbery. In 1974, both the NCS and UCR estimated that 62 percent of offenders committing robbery were black.

\footnotetext{
${ }^{7}$ Recall that the NCS data are restricted to those victim-reported incidents consisting of a lone-offender and face-to-face contact between the victim and the offender.
} 
Data for violent crimes as reported in the 1992 NCVS and 1992 UCR arrest data show much the same pattern as reported earlier by Hindelang (1978). However, there is a slightly larger discrepancy between the two estimates of racial involvement (see table 2 and U.S. Department of Justice 1994b, table 45). For instance, the NCVS estimate of black involvement in robbery in 1992 is 56 percent, whereas the UCR data report that 61 percent of robbery arrestees were black. These differences between UCR and NCVS data do not necessarily indicate increasing selection bias in robbery arrests over time. If black robbery offending is more likely to involve two or more offenders now compared to twenty years ago, such changes would differentially influence the estimates of the percentage black involvement in UCR and NCVS data.

The limitations of using NCVS victim reports to validate UCR arrest data have been discussed elsewhere (e.g., Hindelang 1981; Reiss and Roth 1993; Sampson and Lauritsen 1994), including the concern that race estimates are based solely on NCVS victim reports of loneoffender crimes and that the NCVS data produce incidence rates instead of prevalence rates. The problem of relying on NCVS incidence rates is important to the extent that each racial subgroup contains different proportions of repeat offenders. The UCR data share a similar limitation in that they use arrest incidents as the unit of analysis (and not offenders). The potential inaccuracy of victims' reports of an offender's race in the NCVS data is also a concern, but it is not considered to be a serious limitation. Hindelang (1981), for example, compared NCS rape victims' reports of their offender's age and race to police reports of the offender's demographic characteristics and found substantial agreement. Victims' reports of race agreed with police reports in over 96 percent of the cases. These findings are not definitive, however, because arrests are usually made on the basis of victims' descriptions of offenders.

Since blacks are at greater risk for violent victimization and are disproportionately involved in violent offending, it may not be surprising that the majority of violent crimes are disproportionately intraracial (see Sampson and Lauritsen 1994 for reviews). For example, whites tend to assault other whites and blacks tend to assault other blacks more so than expected, based on chance encounters (Sampson 1984; O'Brien 1987). Racial cross-over is especially rare in nonfelony homicides - that is, killings that occur without an accompanying felony such 
as a robbery or rape (Cook 1987). Because nonfelony homicides tend to be nonstranger homicides, and the routine activities and residences of blacks and whites are in large part segregated, these findings are to be expected. However, felony homicides (e.g., robbery-murders) are more likely to be interracial than are nonfelony homicides because they typically involve strangers (Block 1985; Cook 1987). In felony homicides, as in robberies, black offenders are more likely to victimize whites than white offenders are to victimize blacks (Wilbanks 1985). Yet this is still what we should expect because blacks are the smaller group and have more chances to interact with whites. Variations in the relative sizes of the black and white populations thus explain the patterning of interracial violence (see Sampson 1984; O’Brien 1987; Reiss and Roth 1993).

As noted earlier, it is impossible to validate race differences in certain kinds of crimes reported in UCR arrest data with NCVS victim reports. Common crimes such as burglaries and larcenies do not often result in victim-offender interaction, and therefore validation with NCVS data is not feasible. For these types of crimes, then, we must be less certain of race and ethnic differentials.

\section{Self-Reported Offending}

In an attempt to overcome the limitations of both official statistics and victimization surveys, self-reported delinquency data have been brought to bear on the race question. Many studies, especially those in the 1960s and 1970s, found little or no differences in self-reported offending among juveniles of different racial and ethnic groups (see Hindelang, Hirschi, and Weis 1979, 1981). One reaction to these findings was to attribute racial bias to official statistics. Others posited methodological explanations. In particular, Hindelang, Hirschi, and Weis (1979) argued that self-report studies typically measure less serious forms of common delinquency, whereas official arrest statistics showing race differentials refer primarily to serious index crimes. $\mathrm{Na}$ tionally representative self-report data on serious offense involvement for adults are rare, and cross-method validation has not been completed (Elliott 1994). Consequently, the evidence to date suggests that the domains of behavior are not isomorphic across data sources.

Another critique, in many ways more powerful, is that the selfreport method itself is differentially valid by race, with blacks underreporting certain offenses at higher rates than whites. In a reverse record 
check analysis, Hindelang, Hirschi, and Weis found that black males were least likely to self-report offenses recorded by the police (e.g., 33 percent of total offenses known and 57 percent of serious offenses known to police were not self-reported by black males; Hindelang, Hirschi, and Weis 1981, p. 172). Hence the issue of differential validity according to race is of concern even when the behavior elicited by the self-report method is a serious offense such as burglary, robbery, or weapons violation. ${ }^{8}$

Advances in self-report methodology have resolved some of these issues. For example, Elliott and Ageton (1980) have shown that police and self-report differences in the relationships between race and offense involvement are to a large extent a function of delinquency instrument construction, especially item content and response set range. Using nationally representative data, they found self-reported race (and class) differences in delinquency at the high end of the frequency continuum and for serious offenses like robbery where police contacts are more likely (see also Elliott 1994). Consequently, the magnitude of the race-crime correlation is higher in official statistics than in selfreported data. While limitations exist for both official and self-report data, it thus appears that race differences in offending as recorded in arrest reports and victimization surveys "reflect real differences in the frequency and seriousness of delinquent acts" (Elliott and Ageton 1980, p. 107).

\section{Explaining Racial Disparities in Offending}

Few criminological theories have been designed "a priori" to explain racial differences in official, victimization, or self-report data. Rather, most theories have been applied "post hoc" to race-related differences, not just for offending but victimization as well. In this regard, it is of theoretical relevance that offenders and victims share a similar demographic profile-especially for violence. Both violent offenders and victims of violent crime tend to be young, male, black, and live in urban areas (see Hindelang, Gottfredson, and Garofalo 1978; Gottfredson 1986). Subcultural perspectives even suggest that victims and offenders are often the same people (Wolfgang 1958; Singer 1981). Lifestyle-routine activity theory also tries to explain the overlap among victims and offenders. For example, in analyses of panel data, Laurit-

\footnotetext{
${ }^{8}$ Interestingly, differential validity of self-reported delinquency has also been found in other countries, with some national minorities underreporting known offenses (Junger 1989).
} 
sen, Sampson, and Laub (1991) found that delinquency involvement made independent contributions to victimization risk among adolescents and that increases in victimization, in turn, increased subsequent offending. This pattern, often neglected by criminological theory, suggests that an explanation of offending may go a long way toward explaining racial differences in victimization as well. Nevertheless, most thinking on race and crime focuses on the causes of offending differentials.

There are numerous ways to categorize the many theories devoted to explaining variations in crime. Some of the most common hypotheses used in attempts to explain individual-level race differences in offending are based on constitutional, family socialization, the subculture of violence, and economic inequality/deprivation theories (Wilson and Herrnstein 1985). As most criminologists are aware, constitutional theories are least popular. The idea that IQ, temperament, and other individual characteristics explain the race-crime connection is anathema to many on political and policy grounds. But there are better reasons to reject the constitutional argument-empirical invalidity. Even Wilson and Herrnstein, sympathetic in general to constitutional explanations, largely dismiss them as providing little insight on racial disparities. The reason is simple; there are more variations within any race or ethnic group than between them. As noted earlier, "race" is socially constructed, and the explanation of apparent differences is linked to the fact that race is serving as a proxy for some other set of variables.

A second explanation of race differences in crime is that the family socialization of black children is somehow inadequate. Culture of poverty and lower-class culture theories assert that inadequate socialization can be traced to the female-headed family structure more commonly found among blacks than whites (e.g., Miller 1958), while structurally oriented theories assert that differences in child socialization practices are the consequence of economic deprivation (Kornhauser 1978). Although there is good evidence that family socialization influences children's delinquency and aggressive behavior patterns (e.g., Loeber and Stouthamer-Loeber 1986), there is no consistent evidence that factors such as lack of supervision and erratic or harsh discipline account for race differences in crime net of socioeconomic conditions.

Deviant subcultures have also been proposed to account for group differences in crime. These perspectives vary in details but in general claim that blacks are more likely to commit offenses because they are 
socialized into a culture in which crime, aggressive behaviors, and illegitimate activities are not strongly condemned. The most influential of these perspectives is the subculture of violence thesis (Wolfgang and Ferracuti 1967) which argues that in certain areas and for certain subgroups (i.e., blacks), there is a subcultural value system that supports the use of violence and other behaviors (e.g., sexual machismo) not emphasized in the dominant culture (Curtis 1975). In addition to the methodological difficulties noted earlier, one of the primary weaknesses in the subculture of violence literature has been the problem of tautology - that is, violent behaviors are used to infer the existence of a subcultural system, which in turn is used to explain behavior. There is little evidence from social surveys that black and white Americans differ significantly in their attitudes and values toward crime (Kornhauser 1978; Dilulio 1995). ${ }^{9}$ In addition, empirical support for subcultural explanations requires finding that the normative context of different groups has an influence on behavior independent of structural differences (Kornhauser 1978). Consequently, the role of subcultural value systems in producing race differences in crime remains to be demonstrated.

Finally, racial differences in offending have been attributed to group differences in economic opportunities and success. For example, strain theories argue that individuals who aspire to cultural goals such as wealth, but lack access to the legitimate means for achieving those goals, are most strongly motivated to use illegitimate means for success (see Merton 1938; Blau and Blau 1982). In such theories, race is expected to be related to offending differences insofar as it serves as a proxy variable for access to legitimate means of success. Yet at the individual level, economic strain theories have not fared well empiricallyrace differences persist even after controlling for socioeconomic status (Kornhauser 1978). Relatedly, other race, ethnic, and immigrant groups, such as Chinese, Japanese, and Hispanic, have also experienced economic exclusion but exhibit offending rates much lower than those of African Americans. It is unknown to what extent structural or cultural differences account for lower offending rates among other ethnic

\footnotetext{
${ }^{9}$ Attitudes toward criminal justice issues, however, do differ between blacks and whites. For example, data from the National Opinion Research Center's General Social Surveys show that blacks have been less likely than whites to support the use of capital punishment and are more likely to favor handgun restrictions. Racial divisions in attitudes about criminal justice have become even sharper in the wake of the Rodney King beating and the O. J. Simpson trial.
} 
groups, but clearly socioeconomic status and deprivation alone are inadequate explanations (Wilson and Herrnstein 1985).

Unfortunately then, traditional theories do not seem to have gotten us very far in unraveling race differences. For this reason, recent scholars have begun to look at the macro- and community-level underpinnings of the race-crime connection. Because of its potential importance and the surge in recent research, we discuss the community context of crime in some detail.

\section{The Community Structure of Race and Crime}

Unlike the dominant tradition in criminology that seeks to distinguish offenders from nonoffenders, the macrosocial or community level of explanation asks what it is about community structures and cultures that produce differential rates of crime. As such, the goal of macrolevel research is not to explain individual involvement in criminal behavior but to isolate characteristics of communities, cities, or even societies that lead to high rates of criminality. From this viewpoint the "ecological fallacy"-inferring individual-level relations based on aggregate data-is not at issue because the unit of explanation and analysis is the community.

The Chicago-school research of Shaw and McKay spearheaded the community-level approach of American studies of ecology and crime. In their classic work, fuvenile Delinquency and Urban Areas, Shaw and McKay (1969 [1942]) argued that three structural factors-low economic status, racial or ethnic heterogeneity, and residential mobilityled to the disruption of local community social organization, which in turn accounted for variations in crime and delinquency rates. Subsequent research has generally supported these findings, although most research on violence has examined racial composition-usually percent black - rather than racial heterogeneity per se. Also, while descriptive data show that percentage black is positively and strongly correlated with rates of violence, multivariate research has yielded conflicting findings. Namely, some studies report a sharply attenuated effect of race once other factors are controlled, whereas others report that the percent black effect remains strong (Sampson and Lauritsen 1994, pp. 53-54).

Whether or not race has a direct effect on crime rates, Sampson and Wilson (1995) argue that a major key to solving the race-crime conundrum is traceable to Shaw and McKay (1969 [1942]). Arguably, the most significant aspect of Shaw and McKay's research was their demonstration that high rates of delinquency persisted in certain areas over 
many years, regardless of population turnover (but see Bursik and Webb 1982). This finding, more than any other, led them to reject individual-level explanations of delinquency and focus instead on the processes by which delinquent patterns of behavior were transmitted across generations in areas of social disorganization and weak social controls (Shaw and McKay 1969 [1942], p. 174). This communitylevel orientation led Shaw and McKay to an explicit contextual interpretation of correlations between race or ethnicity and rates of delinquency. Their logic was set forth in a rejoinder to a critique in 1949 by Jonassen, who had argued that ethnicity had direct effects on delinquency. Shaw and McKay countered (1949, p. 614): "The important fact about rates of delinquents for Negro boys is that they too vary by type of area. They are higher than the rates for white boys, but it cannot be said that they are higher than rates for white boys in comparable areas, since it is impossible to reproduce in white communities the circumstances under which Negro children live. Even if it were possible to parallel the low economic status and the inadequacy of institutions in the white community, it would not be possible to reproduce the effects of segregation and the barriers to upward mobility."

Sampson and Wilson (1995) argue that Shaw and McKay's insight almost a half century ago raises interesting questions still relevant today. First, to what extent do rates of black crime vary by type of ecological area? Second, is it possible to reproduce in white communities the structural circumstances under which many blacks live? The first question is crucial, for it signals that blacks are not a homogeneous group any more than are whites. It is racial stereotyping that assigns to blacks a distinct or homogeneous character, allowing simplistic comparisons of black-white group differences in crime. As Shaw and McKay thus recognized, the key point is that there is beterogeneity among black neighborhoods that corresponds to variations in crime rates. To the extent that the structural sources of variation in black crime are not unique, rates of crime by blacks should also vary with social-ecological conditions in a manner similar to whites.

\section{A. Structural Variations in Black Violence}

To disentangle the contextual basis for race and crime requires racial disaggregation of both the crime rate and the explanatory variables of theoretical interest. This approach was used in research that examined racially disaggregated rates of homicide and robbery by juveniles and adults in over 150 U.S. cities in 1980 (Sampson 1987). Substantively, 
this study focused on the role of joblessness among black males in predicting violent crime rates through the mediating influence of black family disruption. The results showed that the scarcity of employed black males relative to black women was directly related to the prevalence of families headed by females in black communities (see also Wilson 1987). Black family disruption was in turn significantly related to rates of black murder and robbery-especially by juveniles-independently of income, region, density, city size, and welfare benefits. The finding that family disruption had a stronger relationship with juvenile violence than adult violence, in conjunction with the inconsistent findings of previous research on individual-level delinquency and broken homes, supports the idea that family structure is related to macrolevel patterns of social control and guardianship, especially regarding youth and their peers (Sampson and Groves 1989). Moreover, the results offer a clue as to why unemployment and economic deprivation have had weak or inconsistent direct effects on violence rates in past research-joblessness and poverty appear to exert much of their influence indirectly through family disruption.

Despite a large difference in mean levels of family disruption between black and white communities, the percentage of white families headed by a female also had a significant effect on white juvenile and white adult violence. The relationships for white robbery were in large part identical in sign and magnitude to those for blacks. As a result, the influence of black family disruption on black crime was independent of alternative explanations (e.g., region, income, density, age composition) and could not be attributed to unique factors within the black community because of the similar effect of white family disruption on white crime. ${ }^{10}$

Black communities are thus not homogeneous in either their crime rates or levels of social organization. Moreover, that the considerable variations in black violence are explained by generic features of urban social structure goes some way toward dispelling the idea of a unique "black" subculture. As Sampson and Wilson (1995) argue, how else can we make sense of the systematic variations within race-for exam-

\footnotetext{
${ }^{10}$ There is some recent evidence that black crime rates are related to some structural features differently than white crime rates (see especially LaFree et al. 1992; Harer and Steffensmeier 1992). However, these studies have been based either on national trends over time or large macrolevel units (standard metropolitan statistical areas). More important, the point is not so much whether all the predictors of white and black crime rates match exactly, but the systematic variation in rates of black violence according to basic features of structural context.
} 
ple, if a uniform subculture of violence explains black crime, are we to assume that this subculture is three times as potent in, say, New York as Chicago (where black homicide differed by a factor of three in 1980)? These distinct variations exist at the state level as well. For example, rates of black homicide in California were triple those in Maryland in 1980 (see Hawkins 1986; Wilbanks 1986). As Sampson and Wilson (1995) ask, must whites then be part of the black subculture of violence in California, given that white homicide rates were also more than triple the homicide rates for whites in Maryland? It does not seem likely. The sources of violent crime appear to be remarkably similar across race and rooted instead in the structural differences among communities, cities, and regions in economic and family organization. It is important to note, however, that a structural perspective need not dismiss wholesale the relevance of culture. Rather, cultural influences may be triggered by structural features of the urban environment (for further elaboration, see Sampson and Wilson 1995).

\section{B. The Ecological Concentration of Race and Social Dislocations}

Bearing in mind the general similarity of black-white variations by social-ecological context, consider the next logical question. To what extent are blacks as a group differentially exposed to criminogenic structural conditions (Sampson and Wilson 1995)? More than forty years after Shaw and McKay's assessment of race and urban ecology, we still cannot say that blacks and whites share a similar environment-especially with regard to concentrated urban poverty. Although approximately 70 percent of all poor non-Hispanic whites lived in nonpoverty areas in the ten largest U.S. central cities in 1980, only 16 percent of poor blacks did. Moreover, whereas less than 7 percent of poor whites lived in extreme poverty or ghetto areas, 38 percent of poor blacks lived in such areas (Wilson et al. 1988, p. 130). Quite simply, race and poverty are confounded in the United States (Land, McCall, and Cohen 1990).

The combination of urban poverty and family disruption concentrated by race is particularly severe. Whereas the majority of poor blacks live in communities characterized by high rates of family disruption, most poor whites, even those from "broken homes," live in areas of relative family stability (Sampson 1987; Sullivan 1989). As an example, consider Sampson and Wilson's (1995) examination of racespecific census data on the 171 largest cities in the United States as of 1980. To get some idea of concentrated social dislocations by race, 
they searched for cities where the proportion of blacks living in poverty was equal to or less than whites and where the proportion of black families with children headed by a single parent was equal to or less than white families. Although the national rate of family disruption and poverty among blacks is two to four times higher than among whites, the number of distinct ecological contexts in which blacks achieve equality to whites is striking. In not one city over 100,000 in the United States do blacks live in ecological equality to whites when it comes to these basic features of economic and family organization. Accordingly, racial differences in poverty and family disruption are so strong that the "worst" urban contexts in which whites reside are considerably better off than the average context of black communities (see also Sampson 1987, p. 354).

Taken as a whole, these patterns underscore what Wilson (1987) has labeled "concentration effects"- the effects of living in a neighborhood that is overwhelmingly impoverished. These concentration effects, reflected in a range of outcomes from degree of labor force attachment to social dispositions, are created by the constraints and opportunities that the residents of inner-city neighborhoods face in terms of access to jobs and job networks, involvement in quality schools, availability of marriageable partners, and exposure to conventional role models. Moreover, the social transformation of inner cities in recent decades has resulted in an increased concentration of the most disadvantaged segments of the urban black population-especially poor, female-headed families with children. Whereas one of every five poor blacks resided in ghetto or extreme poverty areas in 1970, by 1980 nearly two out of every five did so (Wilson et al. 1988, p. 131).

This process of social transformation has been fueled by macrostructural economic changes related to the deindustrialization of central cities where disadvantaged minorities are concentrated (e.g., shifts from goods-producing to service-producing industries; increasing polarization of the labor market into low-wage and high-wage sectors; and relocation of manufacturing out of the inner city). The exodus of middle- and upper-income black families from the inner city has also removed an important social buffer that could potentially deflect the full impact of prolonged joblessness and industrial transformation (Wilson 1987). At the same time, inner-city neighborhoods have suffered disproportionately from severe population and housing loss of the sort identified by Shaw and McKay (1969 [1942]) as disruptive of the social and institutional order. For example, Skogan (1986, p. 206) 
has noted how urban renewal and forced migration contributed to the wholesale uprooting of many urban black communities, especially the extent to which freeway networks driven through the hearts of many cities in the 1950s destroyed viable, low-income communities. Nationwide, fully 20 percent of all central city housing units occupied by blacks were lost in the period 1960-70 alone. As Logan and Molotch (1987, p. 114) observe, this displacement does not even include that brought about by routine market forces (e.g., evictions, rent increases).

An understanding of concentration effects is not complete without recognizing the negative consequences of deliberate policy decisions to concentrate minorities and the poor in public housing. Opposition from organized community groups to the building of public housing in "their" neighborhoods, de facto federal policy to tolerate extensive segregation against blacks in urban housing markets, and the decision by local governments to neglect the rehabilitation of existing residential units (many of them single family homes) have led to massive, segregated housing projects which have become ghettos for minorities and the disadvantaged. The cumulative result is that even given the same objective socioeconomic status, blacks and whites face vastly different environments in which to live, work, and raise their children. As Bickford and Massey (1991, p. 1035) have argued, public housing represents a federally funded, physically permanent institution for the isolation of black families by class and must therefore be considered an important structural constraint on ecological area of residence (see also Massey and Denton 1993). When segregation and concentrated poverty represent structural constraints embodied in public policy and historical patterns of racial subjugation, concerns that individual differences (or self-selection) explain community-level effects on violence are considerably diminished (see also Tienda 1991; Sampson and Lauritsen 1994).

\section{Implications for Explaining Race and Crime}

These differential ecological distributions by race lead to the systematic confounding of correlations between community contexts and crime with correlations between race and crime. Analogous to research on urban poverty, simple comparisons between poor whites and poor blacks are confounded with the finding that poor whites reside in areas which are ecologically and economically very different from those of poor blacks. For example, regardless of whether a black juvenile is raised in an intact or single-parent family, or a rich or poor home, he 
or she is not likely to grow up in a community context similar to whites with regard to family structure and the concentration of poverty (Sampson 1987). Hence, observed relationships involving race and crime are likely to reflect unmeasured advantages in the ecological niches that poor whites occupy (Wilson 1987, pp. 58-60).

Partial evidence supporting this interpretation is found in Peeples and Loeber's (1994) contextual analysis of ethnic difference in delinquency using data from a longitudinal study of male juveniles in Pittsburgh. Consistent with past research, African-American youth exhibited much higher rates of delinquency, especially serious crime, than did whites. However, when the "underclass" status of the subject's residential neighborhood was controlled, race/ethnic differences in delinquency disappeared. Similar to Wilson's (1987) concentration thesis, the "underclass" index was composed of variables that clustered significantly on one factor-joblessness, female-headed families, nonmarital births, poverty, welfare, and percent black. Perhaps most striking, the delinquency rates of African-American youth living in nonunderclass neighborhoods were largely equivalent to those of whites living in nonunderclass areas. Although unable to study whites in disadvantaged areas, Peeples and Loeber's findings support the idea that community context helps us interpret the race-crime association.

With respect to theories on race and crime, community-level inquiry also exposes what Sampson and Wilson (1995) call the "individualistic fallacy"-the often-invoked assumption that individual-level causal relations necessarily generate individual-level correlations. In particular, research conducted using individuals as units of analysisespecially in national probability samples-rarely questions whether obtained results might be spurious and confounded with community-level context. As noted earlier, the most common strategies in criminology search for individual-level (e.g., constitutional), socialpsychological (e.g., relative deprivation), or group-level (e.g., social class) explanations for race and crime. That these efforts have largely failed to explain the race-violence linkage is, we believe, a direct result of the decontextualization that attends reductionist explanations.

Boiled down to its essentials, then, linking theories of community social organization with research on political economy and urban poverty suggests that both historical and contemporary macrosocial forces (e.g., segregation, migration, housing discrimination, structural transformation of the economy) interact with local community-level factors (e.g., residential turnover, concentrated poverty, family disruption) to 
impede the social organization of inner cities. This viewpoint focuses attention on the proximate structural characteristics and mediating processes of community social organization that help explain crime and its connection to race in contemporary American cities, while at the same time recognizing the larger historical, social, and political forces shaping local communities (Sampson and Wilson 1995).

Perhaps most important, the logic of this theoretical strategy suggests that the profound changes in the structure of urban minority communities in the 1970s may hold a key to understanding recent increases in violence. Research has consistently demonstrated the early onset of delinquency and its relative long-term stability (Sampson and Laub 1992). These differences among individuals that are highly stable over time imply that to understand the present high crime rates among youth we must come to grips with their experiences in early adolescence. Much longitudinal research shows that delinquent tendencies are fairly well established at early ages-at eight or so, and certainly by the early teens. Socialization and learning begin even earlier, prompting us to consider the social context of childhood as well.

Considered from this perspective, the roots of urban violence among today's fifteen- to twenty-one-year-old cohorts may in part be attributable to childhood socialization that took place in the late 1970s. Indeed, recent large increases in crime among youth-but not adultsmay be a harbinger of things to come as the massive secular changes that transformed the context of childhood socialization in the 1970s and 1980s are now beginning to exert their influence on those entering the peak years of offending. Cohorts born in 1970-76 spent their childhood in the context of a rapidly changing urban environment unlike that of previous points in recent U.S. history. As documented in more detail by Wilson (1987), the concentration of urban poverty and other social dislocations began increasing sharply at about 1970 and continued throughout the decade and into the early 1980s. For example, the proportion of black families headed by women increased over 50 percent from 1970 to 1984 alone (Wilson 1987, p. 26). Large increases were also seen for the ecological concentration of poverty, racial segregation, and joblessness. By comparison, these social dislocations were relatively stable in earlier decades.

In short, massive social change in the inner cities of the United States during the 1970s and continuing into the 1980s may be the clue to unraveling recent race-related increases in urban violence. This thesis has import for the comparative study of social change in interna- 
tional context, especially considering the economic and racial/ethnic upheavals now emerging globally. Before explicating this idea further, we complete the picture of race and crime by turning to the U.S. system of criminal justice.

\section{Criminal Justice Processing}

Criminologists have produced a voluminous body of research on racial differences in criminal justice processing. This research, conducted over the course of several decades, has covered the major decision points in the justice systems of the United States. Rather than trying to make sense of each and every study, we consult state-of-the-art reviews of research to provide an overview of major findings. In some cases we consider seminal or recent studies in detail, but for the most part we highlight general patterns and trends established in multiple works. We focus on critical decision points in the criminal justice "system" (see U.S. Department of Justice 1988, p. 56)—especially racial disparities in arrest, sentencing, and imprisonment. Although a focus on the criminal justice system leads primarily to research on adult processing, it is important first to consider the literature on race differences in juvenile justice.

\section{A. Fuvenile Fustice}

As Pope and Feyerherm (1990) have argued, minority discrimination in the juvenile and adult systems should be considered separately for two reasons. First, the greater level of discretion allowed in the juvenile justice system may mean that race discrimination is more evident compared to the adult system. Second, because most adult offenders begin their criminal contact with the state through the juvenile justice system, disadvantages incurred as juveniles may influence criminal justice outcomes as adults through characteristics such as prior record, which is typically considered in key decision points throughout life (Pope and Feyerherm 1990, p. 328). ${ }^{11}$

\footnotetext{
${ }^{11}$ It should be noted that in the United States, the age at which the state treats an adolescent as a "juvenile" or an "adult" varies across both jurisdictions and crime types. The age at which an adolescent is considered an adult varies from sixteen to eighteen years of age, although many jurisdictions allow juveniles to be waived to the adult system as young as age thirteen or fourteen if the charge is a serious violent crime. In general, the juvenile justice system is characterized by greater discretion and less formality than the adult system. However, in some larger urban jurisdictions, juvenile justice systems operate with a considerable degree of procedural formality. The juvenile justice system is constituted by many organizational units which vary in caseloads, resources, procedures and practices, structures, and institutional norms.
} 
A recent overview of the literature on minority status and juvenile justice processing summarizes the findings on the relationships between race and postarrest decision making (see Pope and Feyerherm [1990] for more details and an extended bibliography). Pope and Feyerherm (1990) draw three major conclusions about minority status and juvenile-justice decision making. First, two-thirds of the studies reviewed showed evidence of either direct or indirect discrimination against minorities, or a mixed pattern of bias. Direct evidence of disproportionate treatment was inferred when significant race differences in processing (e.g., detention) persisted after controlling for relevant case characteristics (for a recent example, see Wordes, Bynum, and Corley 1994). Indirect evidence of race discrimination was said to exist when a significant race effect operated through some other case characteristic closely associated with race. A mixed pattern of effects was established when an investigator analyzed several decision points and race was found to be significant at some stages but not others, or when race differences existed for specific subgroups of offenders or offenses.

Second, Pope and Feyerherm (1990) argue that studies reporting evidence of differential minority treatment were no less sophisticated in their methodology or statistical techniques than studies reporting otherwise. Inadequacies of research design and execution thus do not appear responsible for evident patterns of discrimination. Third, they report evidence that race differences in outcome may appear minor for any particular decision-making stage, but become more pronounced as earlier decisions accumulate toward a final disposition.

These findings underscore important methodological issues relevant to the study of minority differences in criminal justice processing. As Pope and Feyerherm (1990) note, most research asserts no evidence of discrimination for a processing decision if the statistical significance of the race coefficient is eliminated by controlling for some other individual-level variable (e.g., family structure, prior record). However, as they correctly argue, "logically, what has occurred in these studies is the identification of the mechanism by which differences between white and minority youths are created. Whether these types of variables ought to be used in justice system decision making, and whether they ought to produce the degree of differences between white and minority youths that they appear to produce, are issues that must be addressed" (Pope and Feyerherm 1990, pp. 334-35; see also KempfLeonard, Pope, and Feyerherm 1995).

The importance of understanding the consequences of data aggrega- 
tion is noted as well. Where racially discriminatory practices operate in relatively few jurisdictions in a region, the process of aggregating data across jurisdictions is likely to mask evidence of differential treatment (see also Crutchfield, Bridges, and Pritchford 1994). For example, Pope and Feyerherm found no overall minority discrimination in juvenile justice processing in California and Florida, despite the fact that racially discriminatory practices were evident in several of the counties in each state. Alternatively, they also describe data from a different state in which there appeared to be no racial discrimination within each court or jurisdiction, yet the race composition of the jurisdiction (i.e., county) was associated with between-court differences in the use of incarceration. Specifically, counties with greater proportions of blacks and Hispanics were found to rely more heavily on out-ofhome placement (Pope and Feyerherm 1990, p. 335). An independent analysis of juvenile processing across a representative sample of jurisdictions supports this "macrolevel" pattern. Sampson and Laub (1993a) report that counties with greater poverty and race inequality are more apt to use predispositional detention and adjudicated out-ofhome placement.

In short, the relationship between race and juvenile justice decision making is complex and requires careful methodological consideration. The use of data from multiple levels of analyses is undoubtedly important as both macro- and individual-level factors (including community race composition and inequality, and suspect's race) have been shown to predict the severity of dispositions among juveniles. Furthermore, several multilevel analyses suggest that macro- and individual-level factors interact to produce racial differences in juvenile justice outcomes. In a later section we elaborate on the implications of a contextual perspective for understanding racial differences in justice processing.

\section{B. Police-Citizen Encounters and Arrest}

We now turn to a consideration of research on the sequential nature of processing in the criminal justice system. We begin with the institution that suspects (whether juvenile or adult) are likely to first encounter-the police. In evaluating rival hypotheses on racial differences in criminal offending, research on arrest disparities was covered in Section III (e.g., NCVS victimization reports vs. the UCR). There we saw that, for the most part, racial differences in arrests for "street" crimes are attributable to the differential involvement of blacks in criminal offending irrespective of age (Hindelang 1978, 1981). However, there 
are two other dimensions to policing that bear on race disparities: police-citizen encounters that may or may not result in arrest, and police shootings of civilians.

The literature in the area of police discretion to arrest originated with research on juvenile encounters. In general, the data have shown that when offenses are minor in nature, officers typically rely on the juvenile's demeanor or attitude to determine how they will handle the case (Piliavin and Briar 1964; Black and Reiss 1970). The suspect's race is relevant insofar as it serves as a proxy for police perceptions of disrespectful attitudes, which increase the likelihood of an official write-up or arrest.

Extending the scope of analysis to adults, Smith (1986) found that neighborhood context influenced the willingness of police to arrest and use coercive authority. Smith reports that the police are more likely to arrest, or use or threaten to use force, against suspects in racially mixed or minority neighborhoods. Within these areas, however, suspect's race did not serve as an additional predictor of police behavior. Smith (1986) also reports that black suspects in white neighborhoods are treated less coercively than black suspects in minority neighborhoods and that white suspects are treated similarly regardless of neighborhood. In other words, neighborhood characteristics such as racial composition and socioeconomic status interact with suspect characteristics to predict arrest and use of coercive authority.

Another line of inquiry into police-citizen encounters involves the overrepresentation of blacks in police shootings of criminal suspects. In analyses of data from New York City, Fyfe (1982) reports that blacks were more likely than whites to be shot by police because they were disproportionately involved in armed incidents at the time of the encounter. By contrast, a similar analysis based on data from the city of Memphis showed that blacks were no more likely than whites to be involved in armed incidents, and yet disproportionately more blacks were shot by police while retreating. Fyfe (1982) concludes that in Memphis, police use of deadly force varies significantly according to suspect's race. Similar to the interaction effects noted above, the importance of a suspect's race for predicting police use of deadly force appears to vary across context (e.g., neighborhoods, cities).

\section{Bail}

Following an arrest, the next major point of contact within the criminal justice system centers on whether an accused will be held in deten- 
tion pending case disposition or released on bond (i.e., bail). Research on pretrial release practices by the criminal justice system shows that defendants who are detained prior to prosecution tend to receive more serious penalties on conviction (Goldkamp 1979). For this reason, and because pretrial detention constitutes "punishment" before conviction, discriminatory processes in pretrial release are an important concern. For the overwhelming majority of offenses charged, prosecutors and judges have considerable discretion whether defendants are "released on their own recognizance" or as to the dollar amount of bail requested to secure a pretrial release. United States courts are legally allowed to use dangerousness to the community and flight risk in pretrial decision making. Typically, the court relies on the defendant's employment status, marital status, and length of residence to indicate "community ties" which, in turn, are used to predict whether a defendant is likely to flee the area or fail to appear at trial (Albonetti et al. 1989).

Although few in number, prior studies tend to show that the direct influence of race on pretrial release is insignificant once a defendant's dangerousness to the community (e.g., offense charged, prior record, weapons use) and prior history of failing to appear at trial are controlled. Nonetheless, as Albonetti et al. (1989) show, race is related to bail decision making in complex, interactive ways. In a study of more than 5,000 male defendants across ten federal court districts, Albonetti et al. report that defendants with lower levels of education and income receive significantly more serious pretrial release decisions, controlling for community ties and dangerousness. Moreover, they report that white defendants benefited more from the (nonlegal) effects of education and income than did black defendants with equal resources. Prior record also had a stronger negative effect on pretrial release decisions among blacks than it did for whites. However, dangerousness and offense severity had stronger influences on bail decisions for whites. While these results reveal that under certain conditions whites are treated more severely at pretrial release, in the main they suggest that white defendants "receive better returns on their resources" (Albonetti et al. 1989, p. 80).

\section{Conviction}

The consensus of prior research goes against a simplistic discrimination thesis-in the aggregate, blacks tend to be convicted less than whites (Burke and Turk 1975; Petersilia 1983; Wilbanks 1987, appendix). Several researchers, however, have argued that this finding stems 
from a confounding of case mix (i.e., type of crime charged) with race. Once type of charge against the defendant is controlled in multivariate analysis, the direct influence of race tends to disappear in studies of conviction. As Burke and Turk (1975, pp. 328-29) conclude, "race has no independent effect upon case dispositions" (see also Petersilia 1983, p. 19). With or without control of type of crime, then, there is no consistent evidence that minorities are disadvantaged at the stage of criminal conviction. The caveat here, as elsewhere, concerns race or ethnic comparisons other than black versus white. We have no empirical basis from which to draw conclusions about convictions among Hispanic, Asian, and Native Americans.

It is thus clear that more research is needed on this subject that includes the full array of ethnic groups that make up an increasingly diverse society.

\section{E. Sentencing}

Research on the sentencing of criminal defendants has generated the greatest interest among those studying racial disparities. As Zatz (1987, p. 69) argues, research on whether the legal system discriminates on the basis of racial or ethnic group membership was the question for studies of sentencing in the 1970s and early 1980s. The topic has an even earlier history, however, as Zatz (1987) demonstrates in her review of four "waves" of research on racial disparities. The first wave of research conducted through the mid-1960s tended to suggest that bias against minority defendants was significant. These studies included the research of Thorsten Sellin, in particular his well-known assertion that equality before the law is a social fiction (Sellin 1935).

Wave 2 followed in the wake of civil unrest in the United States and began to address the assertion that race was a determinative factor in sentencing in a more sophisticated way. Wave 1 studies were crude methodologically, and almost none controlled for legally relevant variables in assessing race effects. In an effort to ameliorate these limitations, wave 2 inspired a large number of studies that have been the subject of widely cited and influential reviews by Hagan (1974), Kleck (1981), and Hagan and Bumiller (1983). Kleck (1981) assessed fiftyseven studies, while Hagan and Bumiller (1983) reviewed more than sixty for the National Academy of Sciences. These assessments converged in their conclusion that the effect of race in prior studies was in large part a proxy for the legally relevant factor of prior criminal record-once the latter was controlled the direct effect of race on sentenc- 
ing was for the most part eliminated. That is, the racial disparities in sentencing (e.g., to prison) arose from the greater proportional involvement of minorities in criminal behavior, which was in turn reflected in longer or more serious prior records.

Hagan's and Kleck's exhaustive reviews, covering dozens of empirical studies, were largely responsible for creating what has been labeled by Wilbanks (1987) as the "no discrimination thesis" (NDT). However, as Zatz (1987, p. 73) argues, many criminologists quoting the NDT glossed over two of the caveats that these reviews emphasized. Similar to the concerns raised in research on juvenile justice processing, one caveat was that race might have a cumulative effect on sentencing outcomes by operating indirectly through other variables that disadvantage minority group members. The second is that race may interact with other factors to influence decision making. We return to these arguments below, but for now, it is important to clarify that the NDT refers specifically to the insignificant direct effects of race on sentencing.

Conducted mainly in the late 1970s and 1980s, wave 3 of research witnessed yet another round of methodological refinements, including corrections for "selection bias" (the nonrandom selection of defendants into the system) and "specification error" (the omission of explanatory variables; see Zatz 1987, p. 75). Researchers also investigated historical changes in sentencing practices and expanded the focus to types of crime not previously emphasized (e.g., drug processing). For example, Peterson and Hagan (1984) found that the sentencing of black drug offenders in New York depended on shifting symbolic contexts-minor black dealers were treated more leniently than their white counterparts, but major black dealers ("kingpins") were treated more harshly than white dealers because they were perceived as inflicting further harm on an already victimized nonwhite population (Peterson and Hagan 1984, p. 67). Other research began to examine racial bias in terms of the victim's status rather than that of the offender. This line of inquiry suggests that defendants are more harshly sentenced by the criminal justice system when the victim is white rather than black (Myers 1979).

Research from wave 3 is thus not easily summarized, for many studies began to uncover contradictory findings or began to explore hypotheses tangential to the NDT. For example, some researchers found expected patterns of discrimination while others did not, and a fair number of studies showed that whites received harsher sentences 
than blacks in certain cases (Zatz 1987, pp. 74-78). Overall, though, the thrust of research during this era seemed to shift away from the NDT to the idea that there is some discrimination, some of the time, in some places. These contingencies undermine the broad reach of the NDT, but the damage is not fatal to the basic argument that race discrimination is not pervasive (or systemic) in criminal justice processing.

What Zatz (1987) calls wave 4 of research is still in progress. Based on data from the late 1970s and 1980s and conducted from the 1980s to the present, this era of research continues to use advanced statistical techniques. But perhaps the main distinguishing feature is the research exploitation of policy changes that introduced determinate sentencing. First enacted in the United States in the mid-1970s, the fixed sentencing mandate has grown even stronger, with the latest manifestation found in the politically popular "three strikes and you're out" laws. ${ }^{12}$ In one of the larger studies, Klein, Petersilia, and Turner (1990) analyzed over 11,000 cases in California and found slight racial disparities in sentencing one year after that state had implemented a determinate sentencing act. However, once prior record and other legally relevant variables were controlled, Klein, Petersilia, and Turner (1990, p. 815) found that "racial disparity in sentencing does not reflect racial discrimination." Also analyzing data from California after determinate sentencing, Zatz (1984) found no overt or direct bias against HispanicAmericans compared to Anglos (i.e., non-Hispanic whites).

The research in wave 4 on determinate sentencing is interesting because it shifts attention to prior stages of the system where discretion by prosecutors may potentially disadvantage minorities. In other words, if sentences are (relatively) fixed, then charging and plea bargaining become more crucial in the criminal justice process. Accordingly, some studies have turned to the study of the relatively hidden dimension of prosecutorial discretion. Although little research has accumulated, especially on racial differences in charging (see Wilbanks 1987), Spohn, Gruhl, and Welch (1987) found a pattern of discrimination in favor of female defendants and against blacks and Hispanics. More specifically, their analysis of more than 30,000 cases from Los Angeles County showed that, after adjusting for age, prior record, seriousness of charge, and weapon use, cases against blacks and Hispanics

12 “Three strikes and you're out" laws refer to legislation first enacted in Washington State in 1993 and subsequently replicated elsewhere making the consequence of a third conviction for a violent crime an automatic life sentence without the possibility of parole. The phrase itself is popularly known from its use in the American sport of baseball. 
were significantly more likely to be prosecuted than cases against whites. Spohn, Gruhl, and Welch (1987) did not control for bail status, a factor predictive of prosecution, but the findings are nonetheless provocative in suggesting that blacks and Hispanics in Los Angeles are more likely to be formally prosecuted than whites.

The research on race and plea bargaining is also sparse, but the studies of Miethe and Moore (1986) and Albonetti (1990) both find an insignificant main effect of race on plea negotiations net of control variables. Albonetti (1990) pursues interaction effects and finds that legal factors (e.g., weapon use, prior record, type of counsel) work differently for whites than blacks in a complex fashion. But the reason why blacks are less likely to plead guilty in her data remain unclear, and the fact remains that the main effect of race is insignificant. Hence the NDT fails to be rejected in this case.

The other distinguishing feature of recent research on sentencing is a deeper appreciation for the salience of macrosocial contexts. Primed by the research in wave 3 suggesting interaction and contextual effects, scholars began to design research that could disentangle the role of macrolevel contexts (e.g., county poverty, urbanism) on sentencing. One of the best studies to date of race and sentencing emerges from this concern-Myers and Talarico's The Social Contexts of Criminal Sentencing (1987). Analyzing more than 26,000 felons convicted between 1976 and 1985 in the forty-five judicial courts of Georgia, Myers and Talarico employ state-of-the-art statistical methods to counter the limitations of previous research outlined by Zatz (1987). With the southern state of Georgia as its focus, it is hard to imagine a better test case for discrimination in the modern era. The findings are complex, and as the title would indicate, Myers and Talarico report that sentencing outcomes vary significantly as a function of social context (e.g., urbanization of the county). This pattern supports the contingency model of criminal sentencing and rejects the idea that invariant laws or modes of behavior characterize the "system" as a whole.

In terms of race, however, the data analyzed by Myers and Talarico (1987) clearly failed to support the thesis of systemic race discrimination-even in a contingent manner. As they summarize the book's key findings:

The analyses reported in previous chapters indicate that there is little system-wide discrimination against blacks in criminal sentencing. This is an important finding, because general charges 
of discrimination are common not only in some interpretations of conflict theory, but also in some sectors of the popular and academic press. To be sure, the absence of evidence of systemwide discrimination does not mean that all courts and judges are [color] blind in the administration of criminal law. Interactive analysis revealed context-specific patterns of discrimination. Importantly, however, there were many instances in which blacks received disproportionately lenient punishment. Although this pattern may reflect a paternalism that is just as discriminatory as disproportionate punitiveness, it nonetheless indicates that the courts in Georgia do not have a heavy hand with black defendants in the general systemic sense or in every context where differential treatment is observed. (Myers and Talarico 1987, pp. 170-71)

This conclusion matches that of the U.S. Justice Department's recent survey of felony cases in the seventy-five most populous urban areas in the United States (Smith 1993; Langan 1994). These areas represent the jurisdictions in which most black defendants come into contact with the criminal justice system, and thus the data are useful for describing overall differences in prosecution, conviction, and sentencing of felony cases. The survey findings showed that following a felony charge, blacks were prosecuted at a slightly lower rate than whites (e.g., 66 percent of black defendants were prosecuted compared to 69 percent of whites). Once prosecuted, black defendants were also slightly less likely to be found guilty than were whites ( 75 percent vs. 78 percent). However, of those convicted, blacks were more likely to be sentenced to prison (51 percent vs. 38 percent). Among those sentenced to prison, there were no significant race differences in length of sentence.

Langan (1994) reports that the observed race differences in imprisonment were the result of type of crime, prior record, and aggregation effects. Black defendants were more likely to be charged with robbery or another violent offense than were whites. Also, a greater percentage of the black defendants had prior felony convictions. Examination of aggregation effects revealed that black defendants were more likely to be adjudicated in jurisdictions that were more likely to hand out prison sentences. Yet, within these harsher jurisdictions, blacks were treated no differently than whites. Based on these findings, Langan (1994, p. 51) concludes that the "Justice Department survey provides no evidence that, in the places where blacks in the United States have most of their contacts with the justice system, the system treats them more harshly than whites." It could have been argued, however, that what 
the survey revealed was a potential contextual relationship between race and the decision to imprison.

A recent review of thirty-eight studies on race and sentencing by Chiricos and Crawford (1995) suggests that this latter interpretation is plausible. By separating the evidence on the decision to imprison and the length of sentence once imprisoned, these authors confirm the Justice Department's report; most studies showed that blacks were more likely to be sentenced to prison than were whites, but there was no pattern of race differences in sentence length. However, Chiricos and Crawford also investigated the contextual conditions of the samples used in each of the studies and found that, controlling for crime type and prior record, black defendants were more likely to receive imprisonment in high unemployment areas, in places where blacks constitute a larger percentage of the population, and in the South. This metaanalysis strongly suggests the plausibility of contextual influences on the decision to imprison. As they argue, "these specific structural contexts lend support to the premise that criminal punishment not only responds to crime, but responds as well to specific community conditions" (Chiricos and Crawford 1995, p. 301). Thus unlike Langan's dismissal of the race differences in the decision to imprison, Chiricos and Crawford focus explicitly on the context in which these decisions are most likely to occur. ${ }^{13}$

Langan's interpretation, however, matches those of other scholars such as Petersilia (1985) and Wilbanks (1987) in suggesting that systemic discrimination does not exist. Zatz (1987) is more sympathetic to the thesis of discrimination in the form of indirect effects and subtle racism. But the proponents of this line of reasoning face a considerable burden. If the effects of race are so contingent, interactive, and indirect in a way that has to date not proved replicable, how can one allege that the "system" is discriminatory? At least some part of the differences in the interpretation of existing findings is semantic. For some, any evidence of differential treatment, whether anecdotal or empirical, direct or indirect, or at the individual or jurisdictional level, is indicative of a discriminatory system. For those at the other end of the continuum (e.g., Wilbanks 1987), the term is reserved for widespread and consistent differentials in processing unaccounted for by relevant legal factors. Recognizing these differences in the use of terms implies that the

${ }^{13}$ The findings of the Justice Department may be a function of the urban sampling frame. Chiricos and Crawford (1995) note that black defendants were least disadvantaged in non-Southern urban areas where minority concentration was highest. 
assessment of racial discrimination is not simply a matter of empirical debate.

Perhaps more importantly, "the inconsistency in findings offers clues to the contextual character of possible race effects" (Chiricos and Crawford 1995, p. 284). This assessment suggests that multilevel research designs are necessary to assess the impact of race on within- and between-jurisdiction differences in the decision to imprison. We return to this issue below.

\section{F. Imprisonment Disparities}

The sentencing studies considered to this point are for the most part drawn from one jurisdiction or state. Attempting to make broader contributions to the race-sentencing debate, a series of recent efforts has engaged national-level data to account for the racial disproportionality of U.S. prison populations. Generating considerable attention, the seminal article in this area was published by Blumstein in 1982. To study the racial distribution of state prison populations in 1974 and 1979 , Blumstein used UCR arrest statistics from the same years to estimate the racial composition of offenders committing offenses punishable by imprisonment. Although blacks represented 11 percent of the U.S. population, they comprised approximately 49 percent of the prison population in both 1974 and 1979. However, blacks also represented 43 percent of the arrestees in these years, leading Blumstein to conclude that racial disproportionality in offending explained 80 percent of the racial disproportionality in prison populations.

Using arrest data as a simple indicator of offending is controversial for reasons discussed earlier. Langan (1985) counteracted this problem by replicating Blumstein's analysis with estimates for black offending derived from victims' reports in the NCVS. Essentially, Langan's strategy followed that of Hindelang's (1978) in estimating offenders rather than arrestees. By estimating the expected number of black offenders admitted to prison for the years 1973, 1979, and 1982 using the probability of whites going to prison, Langan was able directly to assess the racial disparity argument by comparing these estimates to the observed number of black offenders admitted to prison. For 1973, there is almost exact agreement between the two estimates-19,344 expected to 19,953 admitted black prisoners. The differences are greater in 1979 and 1982, leading to speculation whether a trend of increasing discrimination was set in motion around 1980 (see below). However, Langan (1985) emphasized the overall agreement of the figures and concluded 
that approximately 85 percent of the disproportionality in prison admissions by race is explained by differential offending.

Crutchfield, Bridges, and Pritchford (1994) extend the BlumsteinLangan strategy by disaggregating racial disproportionality estimates across the fifty states. As did Pope and Feyerherm (1990), they argue that if there is variation across states in the degree to which levels of criminal involvement among blacks explain observed imprisonment rates, studies that aggregate to the national level are likely to mask this variation (Crutchfield, Bridges, and Pritchford 1994, p. 179). Similar to Blumstein and Langan, Crutchfield and colleagues find that for the United States as a whole, the lion's share of variation in the observed racial disproportionality of prisons- 90 percent-is explained by arrest differentials (NCVS estimates of offending are unavailable by state). However, they uncover striking variations in this ratio across the fifty states. In some states such as New York, Pennsylvania, Delaware, and Kentucky, the percentage of imprisonment disparity explained by arrest is virtually 100 -suggesting little to no discrimination. By contrast, in many other states the percent dips well below 100, and in some cases below fifty. States with extreme racial differentials in arrests compared to imprisonment include Massachusetts (40 percent), Idaho (53 percent), Colorado (62 percent), Alabama (54 percent), and Maine (58 percent).

The common denominator in these patterns is hard to discern, although most of the states indicating large racial imbalances in imprisonment decisions are smaller in population, with a relatively low percentage of blacks. It may simply be that the estimates are unreliable due to the small number of cases on which the state-specific disparity ratios are calculated. Crutchfield, Bridges, and Pritchford (1994) interpret them substantively, however, arguing that contextual differences have heretofore been hidden by the tendency of researchers to aggregate data across jurisdictions. Similar to the context-specific arguments of Myers and Talarico (1987) and Zatz (1987), the implication is that multiple-jurisdiction or comparative studies are essential to disentangling racial disproportionality. Put differently, understanding racial disparity requires disaggregation of variations by social structural context. We address this concern further when discussing contextual theories and future research from a comparative perspective.

An update of the 1982 Blumstein study suggests several reasons why disaggregation by crime type might be necessary as well (Blumstein 1993b). First, Blumstein notes the enormous growth in imprisonment 
over the 1979-91 time period. Following decades of relative stability, the 1990 U.S. incarceration rate was nearly triple that of 1975 . Moreover, the total number of drug offenders in prison increased nearly tenfold. Second, the 1991 level of racial disproportionality in incarceration rates remained similar to what it had been in 1979 (seven to one), and overall differences in offending (i.e., arrests) explained slightly less of disproportionality in the 1991 prison rates (76 percent). Third, the importance of the war on drugs becomes particularly pronounced for race differences in incarceration by 1991 . For drug offending, differences in drug arrests accounted for only 50 percent of the race disproportionality in drug incarceration. The government's "war on drugs" was concentrated on an offense that involved high levels of discretion and hence was vulnerable to charges of racist practices. The proportion of drug offenders in U.S. prisons went from 5.7 percent in 1979 to 21.5 percent in 1991. As the distribution of offense types changes in prison populations, it thus becomes crucial to examine the issue of disparity by crime type.

\section{G. Death Penalty}

The ultimate criminal sanction-death-has been the subject of much empirical research and philosophical debate. The United States is the only Western industrialized democracy that permits states to impose capital punishment. In 1972 (Furman v. Georgia), the Supreme Court ordered a halt to executions because it found the application of the death penalty to be arbitrary and racially discriminatory. By 1976 (Gregg v. Georgia) the Supreme Court had reinstated the death penalty as long as states could show that the risk of arbitrariness had been removed through the development of explicit sentencing criteria, separate sentencing hearings, consideration of mitigating circumstances, and automatic appellate review. Nonetheless, research covering the period since the $1976 \mathrm{Gregg}$ decision shows that, controlling for type of homicide, race is related to the prosecutor's decision to seek the death penalty and to imposition of the death penalty (Bowers and Pierce 1980; Radelet 1981; Paternoster 1984; Keil and Vito 1989; Aguirre and Baker 1990; Baldus, Woodward, and Pulaski 1990).

These studies converge in showing that it is the race of the victim interacting with the race of the offender that significantly influences prosecutors' willingness to seek the death penalty, and judges' and juries' willingness to impose a sentence of death. Paralleling the data on convictions, black offenders found guilty of murdering white victims 
are at the highest risk for the death penalty. Offenders (of either race) found guilty of murdering black victims are least likely to receive the death penalty. These differential patterns of risk for the death penalty were found to persist despite stringent controls for the seriousness of the incident (e.g., defendant's deliberation, heinousness of the murder) and other legally relevant factors (see Keil and Vito 1989). ${ }^{14}$

\section{H. Summary}

Recognizing that research on criminal justice processing in the United States is complex and fraught with methodological problems, the weight of the evidence reviewed suggests the following. When restricted to index crimes, dozens of individual-level studies have shown that a simple direct influence of race on pretrial release, plea bargaining, conviction, sentence length, and the death penalty among adults is small to nonexistent once legally relevant variables (e.g., prior record) are controlled. For these crimes, racial differentials in sanctioning appear to match the large racial differences in criminal offending. Findings on the processing of adult index crimes therefore generally support the NDT.

However, research on the decision to imprison suggests that race matters in certain contexts. Controlling for crime type and prior record, black defendants in some jurisdictions are more likely to receive a prison sentence than are white defendants. Research on the juvenile justice system also offers evidence of racial influences on detention and placement, although this disparity is more widespread than contextspecific. Perhaps because the juvenile justice system is more informal, discrimination operates more freely. Moreover, in both the adult and juvenile systems, indirect racial discrimination is plausible. For example, prior record is the major control variable in processing studies and is usually interpreted as a "legally relevant" variable. But to the extent that prior record is contaminated by racial discrimination, indirect race effects may be at work. Although this argument is difficult to assess definitively, it remains a productive hypothesis to be explored. Also tentative but plausible is the idea that race interacts with other individ-

\footnotetext{
${ }^{14}$ While it has been argued that this is evidence of discrimination warranting a moratorium on capital punishment, there are those who argue that such differential treatment warrants increased use of the death penalty. For example, DiIulio (1994) calls attention to the evidence of discrimination against black victims and suggests that justice requires increased use of the death penalty for murderers of all victims. Ironically, calls for increased equity in the application of the death penalty may lead to increased executions of blacks.
} 
ual-level variables (e.g., income, family status) to predict processing. What this means for the NDT hypothesis has yet to be fully determined.

As suggested earlier, one of the most promising lines of inquiry for uncovering discrimination patterns involves the contextual analyses of criminal justice outcomes. As many have argued (Hagan 1987; Myers and Talarico 1987; Sampson and Laub 1993a; Chiricos and Crawford 1995), the key to resolving racial differences in processing may turn in large part on contextual or macrolevel differences. This parallels the arguments made in favor of a community-level interpretation of racial differences in criminal offending. As the next section explores, recent moves in theories of official social control and processing have also adapted this contextual theme.

\section{Explaining Race-Ethnic Disparities in Criminal Justice}

Most criminal justice research has drawn on consensus and conflict perspectives of society (Hagan 1989). According to the consensus view, there is an assumption of shared values, where the state is organized to protect the common interests of society at large. Criminal law is seen as an instrument to protect the interests of all, and punishment is based on legally relevant variables (e.g., seriousness of the offense, prior record).

In contrast, conflict theorists view society as consisting of groups with conflicting and differing values and posit that the state is organized to represent the interests of the powerful, ruling class. Criminal law is thus viewed as an instrument to protect the interests of the powerful and the elite, and punishment is based to a large extent on extralegal variables (e.g., race, social class). A major proposition drawn from conflict theory is that groups which threaten the hegemony of middleand upper-class rule are more likely to be subjected to intensified social control-more criminalization, more formal processing by the criminal justice system, and increased incarceration compared with groups that are perceived as less threatening to the status quo (see also Brown and Warner 1992). Furthermore, conflict theorists have argued that minorities (especially blacks), the unemployed, and the poor represent such threatening groups (see also Turk 1969; Chambliss and Seidman 1971; Jackson and Carroll 1981; Liska and Chamlin 1984; Brown and Warner 1995). ${ }^{15}$

\footnotetext{
${ }^{15}$ There is some evidence to suggest that the relationship between percent black and increased social control is curvilinear (see e.g., Jackson and Carroll 1981). Liska and
} 
The criticisms of conflict theory are well known. Elites do not form a unitary whole, monopolize decision making, or appear particularly vulnerable to the objective threats of subordinates (Liska 1987; Tittle 1994). Perhaps more damaging, the evidence on personal and property crimes points to legal variables as the prime determinants of criminal justice processing.

Attempting to transcend the limitations of traditional conflict theory, a recent school of thought has forged a more contextually nuanced appreciation of minority group threat. While there may indeed be a general consensus in society on core values, it is not the objective level of threat but rather the symbolic aspect of social conflict that may be the salient feature driving crime control (Myers 1989). For instance, Tittle and Curran (1988) emphasize perceptions of threat that "provoke jealousy, envy, or personal fear among elites" rather than the actual threat these groups represent to reigning political positions. Supporting this notion, they found differential sanctioning of juveniles in Florida counties depending on the size of the nonwhite population. Moreover, Tittle and Curran found the largest discriminatory effects in juvenile justice dispositions for drug and sexual offenses which they argue "represent overt behavioral manifestations of the very qualities [that] frighten white adults or generate resentment and envy" (Tittle and Curran 1988, p. 52). Tittle (1994, pp. 39-46) elaborates this finding with reference to the "emotional significance" of crime, especially stereotypical attributions of threat associated with the conflation of race, aggression, and sexual promiscuity.

These ideas are consistent with a study in Washington State, where nonwhites were sentenced to imprisonment at higher rates in counties with large minority populations (Bridges, Crutchfield, and Simpson 1987). Follow-up interviews with justice officials and community leaders revealed a consistent public concern with minority threat and "dangerousness." With crime conceptualized as a minority problem, leaders openly admitted using race as a code for certain patterns of dress and styles of life (e.g., being "in the hustle") thought to signify criminality. It was decision makers' perceptions of minority problems as concentrated ecologically that seemed to reinforce the use of race as a screen for criminal attribution (Bridges, Crutchfield, and Simpson 1987, p. 356). Similarly, Irwin (1985) notes the importance of subjective perceptions of "offensiveness," which are determined by social sta-

Chamlin (1984) suggest that when minorities become so large as to represent a majority, the criminal justice system takes on the stance of "benign neglect." 
tus and ethnic group context. Groups deemed as threatening (often when reaching a threshold size) and offensive to the dominant majority are seen as the "rabble class-detached and disreputable persons." Irwin $(1985$, p. xiii) argues that the primary purpose of jails in the United States is to manage society's rabble class.

Attributions of criminality to subordinate ethnic populations have been found in other stratified societies as well. In Israel, for example, Fishman, Rattner, and Weiman (1987) found that public assignment of criminal intent was directly related to ethnic divisions. Arab Israelis, followed by Sephardic Jews, were most likely to be perceived by respondents as criminal. With recent unrest in the occupied territories, charges have also flared anew that Israeli Arabs are being targeted for increased social control by Israeli police, especially in impoverished towns where Arab concentrations are high (Hedges 1994).

In short, recent theory has turned to a macrosociological orientation by focusing on the symbolic and contextual aspects of minority group threat. In this viewpoint, "the poor," "the underclass," and "the rabble" (i.e., poor minorities) are perceived as threatening not only to political elites, but to "mainstream America"-middle-class and working-class citizens who represent the dominant majority in American society. This perspective suggests that we need to take into account the joint effects of race and poverty. Interestingly, it is here that the pejorative connotations of the term "underclass" become quite relevant. Although criticized by some social scientists (e.g., Gans 1991), the term has nonetheless been appropriated by the media and public at large as a code for dangerous, offensive, and undesirable populations that threaten social stability and a sense of order. As the social historian Michael Katz (1993, p. 4) has noted, "underclass" has become a public metaphor for social transformation in the United States, conjuring up images of group alienation and danger-a collectivity "outside of politics and social structure," a "terrain of violence and despair." Embodying its controversial nature, then, the term "underclass" captures the stereotype of pathological danger relevant to a theoretical concern with how race-class divisions bear on official social control and the "crisis in penality" (see Feeley and Simon 1992, p. 467; McGarrell 1993a, p. 11; Simon 1993, p. 5).

\section{A. Structural Changes in Underclass Inequality}

Debates on the underclass are linked, of course, to demographic evidence on the increasing size and concentration of the urban poverty population. A great deal of sociological attention has centered on the 
growing entanglement in urban areas of neighborhood poverty with other social dislocations such as joblessness, family disruption, high rates of infant mortality, and a host of factors that are detrimental to social development (e.g., school dropout). As noted earlier, the changing neighborhood context of poverty was highlighted by William Julius Wilson in The Truly Disadvantaged (1987), where he argued that the social transformation of the inner city has resulted in an increased geographical concentration of race, poverty, and urban social dislocations.

Recent evidence suggests that the clustering of economic and social indicators appears not only in 1990 and in neighborhoods of large cities, but also for the two previous decennial periods and at the level of macrosocial units as a whole. For example, Land, McCall, and Cohen (1990) present evidence that concentration effects grew more severe from 1970 to 1980 in U.S. cities and metropolitan areas, while Coulton et al. (1995) document an increasing clustering of indicators of social disadvantage (e.g., poverty, family disruption, welfare) in neighborhoods of Cleveland during the 1980s.

Recent data point to the existence of a large "underclass" population in rural areas, especially in the South. Using 1990 data, O'Hare and Curry-White (1992, p. 8) conclude that there is a large rural underclass of both whites and blacks that has not been recognized by researchers in the past and that blacks in the rural South actually have a higher prevalence of underclass characteristics than do blacks in the large cities of the urban North. Adding to this picture, the term "underclass" has recently been applied to poor whites (Murray 1993) in a call for immediate public action to stem a host of social ills usually associated in the American mind with blacks (e.g., out-of-wedlock births, welfare, crime). In a fascinating revision of the once-common stereotype of "white trash," the idea of an emerging "white underclass" that threatens to drag down a society already weakened by the black underclass is now being fostered in contemporary debate. Thus while race and poverty are strongly connected in ecological space, the wide reporting of Murray's (1993) alarm on the white underclass suggests that inequality and class tensions have extended beyond the confines of the African-American community (one might note also the general increases in hate speech and ethnic intolerance).

\section{B. Drugs and Minorities}

The symbolic nature of the "underclass" threat seems to have been operative in the recent "war on drugs" in the United States. Peterson 
and Hagan's (1984) analysis of drug enforcement activity during the 1960s and 1970s documents the beginning of a shifting concern with drugs and crime in society and illustrates the need to consider historical context in understanding criminal justice operations related to race. More recently, Myers (1989) found increased punitiveness for nonwhite drug dealers, underscoring the need to examine race in conjunction with drug use and drug trafficking in a particular historical context.

Two trends emerged during the 1980s that reinforce these claims. The first was the increasing number of black males under correctional supervision (Mauer 1990), and the second saw increasing punitiveness toward drug offenders, especially blacks and users of cocaine (Belenko, Fagan, and Chin 1991; Blumstein 1993a; McGarrell 1993b). By the 1990s, race, class, and drugs became intertwined; it is difficult if not impossible to disentangle the various elements of the problem. Moreover, the war on drugs in the 1980s embodied a different personae than earlier wars, leading many to charge racially discriminatory practices by the criminal justice system in the processing of drug offenders (Feeley and Simon 1992, pp. 461-70; Jackson 1992; Tonry 1995). Particularly relevant to this thesis, recall Tittle and Curran's (1988) finding that the largest discriminatory effects on juvenile dispositions concerned drug offenses.

Data from the 1980s support concerns about the changing dynamics of race and drugs. For instance, while the number of arrests for drug abuse violations by white juveniles declined 28 percent in 1985 compared with 1980, the number of arrests for drug abuse violations by black juveniles increased 25 percent over the same time period (Uniform Crime Reports 1980, 1985). Furthermore, data on arrest rate trends by race show that in 1980 the rate of drug law violations was nearly equal for whites and blacks; however, during the decade of the 1980s, white rates declined while black rates increased markedly (Snyder 1992). Juvenile court data show that the number of white youth referred to court for drug law violations declined by 6 percent between 1985 and 1986; the number of referrals for black youth increased by 42 percent (Snyder 1990). The disproportionate increase in the number of black youth detained also seemed linked to the increased number of black drug law violators referred to court. More generally, Blumstein (1993a) has shown that the dramatic growth in state prison populations during the 1980s was driven in large part by increasing admissions of blacks on drug convictions. 
These trends suggest a recent and increasing punitiveness toward drug offenders-especially those perceived to be gang members from a growing underclass population (Feeley and Simon 1992, pp. 467-69; Jackson 1992, pp. 98-100). Drawing on a revised conflict theory, Sampson and Laub (1993a) argue that the rising concentration of socioeconomic disadvantage corresponds precisely with that population perceived as threatening, and the population at which the war on drugs has been aimed. The dual image of "underclass" offenders and the evils of "crack cocaine" thus appears to have triggered a "moral panic" (Goode and Ben-Yehuda 1994; Chiricos and Crawford 1995) in the middle class as well, further reinforcing a drug war by law enforcement.

At the macro level, Sampson and Laub (1993a) specifically hypothesized that counties characterized by racial inequality and a large concentration of the "underclass" (i.e., minorities, poverty, female-headed families, welfare) were more likely than other counties to be perceived as containing offensive and threatening populations and as a result experience increased punitiveness and hence social control by the juvenile justice system (see also Feeley and Simon 1992, pp. 467-69; Jackson 1992, pp. 98-100). A static version of this hypothesis found preliminary support in Sampson and Laub's (1993a) cross-sectional analysis of approximately 200 counties in 1985. Aggregating court records to the county level, they found that underclass poverty and racial income inequality were associated with higher levels of juvenile confinement (secure detention and out-of-home placement), especially for drug offenses. The effects of underclass poverty also tended to be larger for black juveniles than for white juveniles. In sum, while overt racial discrimination at the individual level appears to be weak, a body of recent contextual evidence suggests that a different scenario may be at work for macrolevel variations in juvenile and adult court processing.

\section{Implications for the Future}

In his review essay on studies of criminal sentencing, John Hagan $(1987$, p. 426$)$ asks: "Why has race so preoccupied us in the study of the criminal justice system?" Indeed, research in the U.S. has embarked on a seemingly unending search for racial influences on criminal justice processing. Hagan's answer is that race and sentencing are symbolically linked considerations in the criminal justice system, "giving the most visible expression to the value we place on equity in this 
system" (Hagan 1987, p. 426). In other words, the United States prides itself on the symbolism of equality before the law, and any threat of racial bias serves to undermine a major linchpin of the system. It is thus understandable that racial biases, even if seemingly infrequent, have been the subject of much recent concern in the United States.

Strong predictions from conflict theory and ideological beliefs notwithstanding (e.g., MacLean and Milovanovic 1990; Mann 1993), the results of this search have not been kind to a simplistic "discrimination thesis." As shown in this essay, racial discrimination emerges some of the time at some stages of the system in some locations, but there is little evidence that racial disparities reflect systematic, overt bias on the part of criminal justice decision makers. Rather, the most compelling evidence concerning racial discrimination in the administration of justice involves community and national constructions of "moral panics" and political responses to those contexts. For example, Tonry (1995) points out that the war on drugs was initiated at a time when national drug use patterns had already exhibited a considerable decline. Tonry further argues that the politically charged war on drugs, with its legislative and budgetary emphasis on the type of drug most likely to be used and detected in black disadvantaged urban areas (i.e., "crack" cocaine), could be viewed as racially discriminatory in intent and consequences. ${ }^{16}$

In addition, even though overt race discrimination in criminal justice processing appears to be a problem restricted to specific spatial and temporal contexts, the fact remains that racial disparities in crimes other than drugs have reached a critical stage in the United States. Not only is homicide the leading cause of death among young black males and females, it is now the case that the majority of persons in state and federal prisons are black (U.S. Department of Justice 1995). As indicated earlier, the incarceration rate of black males is currently seven times the rate for white males (2,678 vs. 372 per 100,000). Even more striking, approximately 6.3 percent of all black males ages twenty-five to twenty-nine are serving time in state prisons (U.S. Department of Justice 1994c), and Mauer (1990, pp. 3, 9) estimates that one of every four black men are processed by the criminal justice system each year. With such enormous disproportionality in sanctioning, it should be of

${ }^{16}$ The U.S. federal drug control budget increased from approximately 2.4 billion dollars in 1984 to more than 12.1 billion dollars in 1994 (Executive Office of the President 1994). 
little comfort that most of the disparity is a result of differential involvement in nondrug criminal offending.

\section{A. Four Crucial Questions}

We believe that to more fully understand racial disparities in crime and justice, at least four areas are in need of further research. First, it is clear that racial differences in criminal victimization and offending, especially for violence, must be studied from a more complex, multilevel perspective (see Sampson and Lauritsen 1994). A lesson learned from our review is that prior theory on criminal offending is usually couched at the level of analysis least likely to yield racial differences-the individual. Posing the problem in a contextual framework, however, suggests that the relationship between race and criminal offending varies substantially across ecological contexts. With few exceptions, criminologists have only recently realized the extent to which correlations between community contexts and crime are confounded with associations between race and crime. Macrolevel analysis thus offers an alternative mode of inquiry into the social bases of race and crime (Sampson and Wilson 1995).

Second, the role that formal sanctioning plays in producing cumulative disadvantage across the life course of individuals requires a new agenda of research. As suggested throughout our synthesis, the voluminous research on the direct effects of race on conviction, sentencing, and other later stages of adult processing (e.g., imprisonment) appears to have reached a dead end. We know that by the time adults penetrate the justice system to the later stages of sentencing and imprisonment, decision makers rely primarily on prior record and seriousness to dispose of cases. But it is in the juvenile justice system that race discrimination appears most widespread-minorities (and youth in predominantly minority jurisdictions) are more likely to be detained and receive out-of-home placements than whites regardless of "legal" considerations. Because processing in the juvenile justice system is deeply implicated in the construction of a criminal (or "prior") record, experiences as a juvenile serve as a major predictor of future processing. Yet surprisingly little is known about how experiences in the juvenile justice system influence relationships with the police and criminal justice system as youth age into adulthood (Pope and Feyerherm 1990). Rather than more studies of adults in the legal versus extralegal mold, research is thus needed to track offenders backward and forward in time to understand the dynamics of criminal careers. This implies a 
life-course perspective that attempts to bridge the gap between adolescent and adult experiences and to unravel the dynamics of cumulative disadvantage associated with race or ethnicity. In particular, attention to the consequences of disproportionate detention and imprisonment must be a priority (see Sampson and Laub 1993b).

Third, despite the volume of previous research on race and ethnic comparisons, we know very little about criminal justice processing other than for blacks and whites. Quite simply, there is little empirical basis from which to draw firm conclusions for Hispanic, Asian, and Native Americans. As seen at the outset, the United States is becoming increasingly diverse largely because of the growing Asian- and Hispanic-American populations. Recent immigration from Mexico and Cuba in particular is reshaping the landscape of many American cities. Hence, the future picture of criminal justice processing may be closely tied to the experiences of race or ethnic groups that have heretofore been neglected by mainstream criminological research. As noted earlier, such analyses will also benefit greatly from work on the changing social constructions of race and ethnic identities in the United States.

Fourth, the extent to which crime wars are waged disproportionately against minorities needs to be examined from a contextual, social constructionist perspective (Best 1990; Goode and Ben-Yehuda 1994; Hawkins 1995). As discussed earlier, the recent drug war in the United States has had its greatest effect on the lives of minorities. While drug arrests have declined among whites, they have skyrocketed among blacks. And while "crack" cocaine has generated an intense law enforcement campaign in our nation's black ghettos, "powder" cocaine use among whites is quietly neglected (perhaps even portrayed as fashionable). These differences cannot be attributed solely to objective levels of criminal danger, but rather to the way in which minority behaviors are symbolically constructed and subjected to official social control (Chambliss 1995; Tonry 1995). As conflict theorists argue, the study of race discrimination in sentencing, controlling for crime type, is irrelevant insofar as "moral panics," legislation, and enforcement activities are designed to target the kinds of lifestyles or areas associated with racial minorities. Hence, close attention to how crime is defined and the social construction of social "problems" is necessary to the study of racial disparity in criminal justice (Goode and Ben-Yehuda 1994).

\section{B. The Global Picture}

Because of the nearly overwhelming complexity of these proposed areas of research, it is with an international, comparative approach that 
we feel the greatest gains will be made. As Ruback and Weiner (1993, p. 195) note, comparative analyses "take advantage of the fact that influences that are causally confounded in their relationships to [crime] within one society or culture are often unconfounded when many societies or cultures are examined." The objective of a comparative approach is to understand how complex causal influences are moderated or mediated by individual and contextual factors. Comparative research also permits the uncovering of etiological universals, and the discovery that variables assumed to be universal have effects only under unique social and cultural circumstances (Munroe, Munroe, and Whiting 1981). Furthermore, comparative analyses provide insights into the assumptions underlying a given society's definitions of race and ethnicity.

Applying a comparative framework to racial disparities in crime and justice raises a host of salient questions. Among many others, a crossnational perspective needs to address variations in how race and ethnicity are related to patterns of offending and victimization across societies. For example, are race and ethnicity effects "explained" in other societies as they are in the United States? What are the relevant theoretical constructs (e.g., community context, cultural heterogeneity, concentration of economic deprivation), and how are they manifested? What do minority groups disproportionately involved in offending have in common across societies? How are historical patterns of racial and ethnic subjugation similar or different? What role does skin color play as opposed to cultural differentiation among groups (Mann 1993)? How do ethnic conflicts over immigration influence crime and social control?

Racial disparities in criminal justice sanctioning are also ripe for comparative study across time and place. At a fundamental level, research has yet to explicate in a systematic way the nature of macrocomparative variations in race and ethnic disparities across societies and epochs of different political, economic, and social structures. For example, we need to be reminded that moral panics have long existed-from the Renaissance witch craze from the fourteenth to the seventeenth century to the "reefer madness" of the 1930s in America to present-day outcries over satanic ritual abuse on a mass scale (Goode and Ben-Yehuda 1994). Under what cultural, structural, and temporal conditions do such moral panics typically arise? Why are accompanying wars waged disproportionately against minorities (e.g., females and blacks)? At the macrocomparative level, a contextual constructionist approach may also shed light on how the structures and 
cultures of criminal justice organizations contribute to racial or ethnic discrimination.

To be sure, these are only a sampling of the questions that a comparative approach to race and ethnicity might address. But addressing them is a necessary first step toward eliminating racial disparities at all levels of the criminal process, not just in the United States but globally as well. As the 1992 riots in Los Angeles suggest, until racial disparities in crime and justice are reduced, the social stability of the criminal justice system-and perhaps the social structure of the United Stateswill remain in doubt. Unfortunately, as ethnic and racial conflicts continue to escalate around the globe (Williams 1994), the United States may be a signpost for future trends.

\section{RE F E R E N C E S}

Aguirre, Adalberto, and David Baker. 1990. "Empirical Research on Racial Discrimination in the Imposition of the Death Penalty." Criminal fustice Abstracts 22:135-53.

Albonetti, Celesta. 1990. "Race and the Probability of Pleading Guilty." Fournal of Quantitative Criminology 6:315-34.

Albonetti, Celesta, Robert Hauser, John Hagan, and Ilene Nagel. 1989. "Criminal Justice Decision Making as a Stratification Process: The Role of Race and Stratification Resources in Pretrial Release." Fournal of Quantitative Criminology 5:57-82.

Baldus, David, George Woodward, and Charles Pulaski. 1990. Equal fustice and the Death Penalty: A Legal and Empirical Analysis. Boston: Northeastern University Press.

Belenko, Steven, Jeffrey Fagan, and Ko-Lin Chin. 1991. "Criminal Justice Responses to Crack." Fournal of Research in Crime and Delinquency 28:55-74.

Best, Joel. 1990. Threatened Children. Chicago: University of Chicago Press.

Bickford, Adam, and Douglas Massey. 1991. "Segregation in the Second Ghetto: Racial and Ethnic Segregation in American Public Housing, 1977." Social Forces 69:1011-36.

Black, Donald, and Albert J. Reiss, Jr. 1970. "Police Control of Juveniles." American Sociological Review 35:63-77.

Blau, Judith, and Peter M. Blau. 1982. "The Cost of Inequality: Metropolitan Structure and Violent Crime." American Sociological Review 47:114-29.

Block, Carolyn R. 1985. "Race/Ethnicity and Patterns of Chicago Homicide, 1965 to 1981." Crime and Delinquency 31:104-16.

Blumstein, Alfred. 1982. "On the Racial Disproportionality of the U.S. States' Prison Population." Fournal of Criminal Law and Criminology 73:1259-81. 
1993a. "Making Rationality Relevant." Criminology 31:1-16.

1993b. "Racial Disproportionality of U.S. Prison Populations Revisited." Colorado Law Review 64:743-60.

- 1995. "Violence by Young People: Why the Deadly Nexus?" National Institute of Fustice fournal 229:2-9.

Bowers, William, and Glenn Pierce. 1980. "Arbitrariness and Discrimination under Post-Furman Capital Statutes." Crime and Delinquency 74:10671100.

Bridges, George, Robert Crutchfield, and Edith Simpson. 1987. "Crime, Social Structure and Criminal Punishment: White and Nonwhite Rates of Imprisonment." Social Problems 34:345-61.

Bridges, George, and Joseph Weis. 1989. "Measuring Violent Behavior: Effects of Study Design on Reported Correlates of Violence." In Violent Crime, Violent Criminals, edited by Neil Weiner and Marvin Wolfgang. Beverly Hills, Calif.: Sage.

Brown, M. Craig, and Barbara D. Warner. 1992. "Immigrants, Urban Politics, and Policing in 1900." American Sociological Review 57:293-305.

- 1995. "The Political Threat of Immigrant Groups and Police Aggressiveness in 1900." In Ethnicity, Race, and Crime: Perspectives across Time and Place, edited by Darnell Hawkins. Albany: State University of New York Press.

Burke, Peter, and Austin Turk. 1975. "Factors Affecting Post Arrest Decisions: A Model for Analysis." Social Problems 22:313-32.

Bursik, Robert J., Jr., and Jim Webb. 1982. "Community Change and Patterns of Delinquency." American fournal of Sociology 88:24-42.

Chambliss, William J. 1995. "Crime Control and Ethnic Minorities: Legitimizing Racial Oppression by Creating Moral Panics." In Etbnicity, Race, and Crime: Perspectives across Time and Place, edited by Darnell Hawkins. Albany: State University of New York Press.

Chambliss, William J., and Robert B. Seidman. 1971. Law, Order, and Power. Reading, Mass.: Addison-Wesley.

Chiricos, Theodore G., and Charles Crawford. 1995. "Race and Imprisonment: A Contextual Assessment of the Evidence." In Etbnicity, Race, and Crime: Perspectives across Time and Place, edited by Darnell Hawkins. Albany: State University of New York Press.

Cohen, Lawrence, and Marcus Felson. 1979. "Social Change and Crime Rate Trends: A Routine Activities Approach." American Sociological Review 44:588-607.

Cook, Philip. 1987. "Robbery Violence." Journal of Criminal Law and Criminology 78:357-76.

Coulton, C., J. Korbin, M. Su, and J. Chow. 1995. "Community Level Factors and Child Maltreatment Rates." Child Development 66:1262-76.

Crutchfield, Robert, George Bridges, and Susan Pritchford. 1994. "Analytical and Aggregation Biases in Analyses of Imprisonment: Reconciling Discrepancies in Studies of Racial Disparity." Fournal of Research in Crime and Delinquency 31:166-82.

Curtis, Lynn. 1975. Violence, Race, and Culture. Lexington, Mass.: Heath. 
DiIulio, John, Jr. 1994. “The Question of Black Crime." Public Interest 117:332.

$\rightarrow$ Elliott, Delbert. 1994. "Serious Violent Offenders: Onset, Developmental Course, and Termination-the American Society of Criminology 1993 Presidential Address." Criminology 32:1-21.

Elliott, Delbert, and Suzanne Ageton. 1980. "Reconciling Race and Class Differences in Self-Reported and Official Estimates of Delinquency." American Sociological Review 45:95-110.

Executive Office of the President. 1994. "National Drug Control Strategy: Budget Summary." Washington, D.C.: Office of National Drug Control Policy.

$\rightarrow$ Feeley, Malcolm, and Jonathan Simon. 1992. "The New Penology: Notes on the Emerging Strategy of Corrections and Its Implications." Criminology 30:449-74.

Fingerhut, Lois. 1993. "The Impact of Homicide on Life Chances: International, Intranational and Demographic Comparison." In Proceedings of the Second Annual Workshop of the Homicide Research Working Group. Washington, D.C.: U.S. Department of Justice.

Fingerhut, Lois, and J. Kleinman. 1990. "International and Interstate Comparisons of Homicide among Young Males." Fournal of the American Medical Association 263:3292-95.

Fingerhut, Lois, J. Kleinman, E. Godfrey, and H. Rosenberg. 1991. "Firearms Mortality among Children, Youth, and Young Adults 1-34 Years of Age, Trends and Current Status: United States, 1979-88. Montbly Vital Statistics Report 39(11):1-16.

Fishman, Gideon, Arye Rattner, and Gabriel Weiman. 1987. "The Effect of Ethnicity on Crime Attribution." Criminology 25:507-24.

Fyfe, James. 1982. "Blind Justice: Police Shootings in Memphis." Journal of Criminal Law and Criminology 73:707-22.

Gans, Herbert. 1991. "The Dangers of the Underclass: Its Harmfulness as a Planning Concept." In People, Plans, and Places, edited by H. Gans. New York: Columbia University Press.

Garofalo, James. 1987. "Reassessing the Lifestyle Model of Criminal Victimization." In Positive Criminology, edited by M. Gottfredson and T. Hirschi. Newbury Park, Calif.: Sage.

Goldkamp, John. 1979. Two Classes of Accused: A Study of Bail and Detention in American Fustice. Cambridge, Mass.: Ballinger.

Goode, Erich, and Nachman Ben-Yehuda. 1994. "Moral Panics: Culture, Politics, and Social Construction." Annual Review of Sociology 20:149-71.

Gottfredson, Michael. 1986. "Substantive Contributions of Victimization Surveys." In Crime and 7ustice: An Annual Review of Research, vol. 7, edited by Michael Tonry and Norval Morris. Chicago: University of Chicago Press.

Hagan, John. 1974. "Extra-legal Attributes and Criminal Sentencing: An Assessment of a Sociological Viewpoint." Law and Society Review 8:357-84.

- 1987. "Review Essay: A Great Truth in the Study of Crime." Criminology 25:421-28. 
$\rightarrow-1989$. "Why Is There So Little Criminal Justice Theory? Neglected Macro- and Micro-Level Links between Organization and Power." fournal of Research in Crime and Delinquency 26:116-35.

Hagan, John, and Kristen Bumiller. 1983. "Making Sense of Sentencing: A Review and Critique of Sentencing Research." In Research on Sentencing: The Search for Reform, edited by Alfred Blumstein, Jacqueline Cohen, Susan Martin, and Michael Tonry. Washington, D.C.: National Academy Press.

Harer, Miles, and Darrell Steffensmeier. 1992. "The Differing Effects of Economic Inequality on Black and White Rates of Violence." Social Forces 70:1035-54.

Hawkins, Darnell, ed. 1986. Homicide among Black Americans. Lanham, Md.: University Press of America.

- 1995. "Ethnicity, Race, and Crime: A Review of Selected Studies." In Ethnicity, Race, and Crime, edited by Darnell Hawkins. Albany: State University of New York Press.

$\rightarrow$ Hawley, F. Frederick, and Steven F. Messner. 1989. "The Southern Violence Construct: A Review of Arguments, Evidence, and the Normative Context." fustice Quarterly 6:481-511.

Hedges, Chris. 1994. "Among Israeli Arabs, Latent Anger Explodes." New York Times (March 1), p. A7.

Hindelang, Michael. 1978. "Race and Involvement in Common-Law Personal Crimes." American Sociological Review 43:93-109.

- 1981. "Variations in Sex-Race-Age-Specific Incidence Rates of Offending." American Sociological Review 46:461-74.

Hindelang, Michael, Michael Gottfredson, and James Garofalo. 1978. Victims of Personal Crime: An Empirical Foundation for a Theory of Personal Victimization. Cambridge, Mass.: Ballinger.

Hindelang, Michael, Travis Hirschi, and Joseph Weis. 1979. "Correlates of Delinquency: The Illusion of Discrepancy between Self-Report and Official Measures." American Sociological Review 44:995-1014.

- 1981. Measuring Delinquency. Beverly Hills, Calif.: Sage.

Irwin, John. 1985. The fail: Managing the Underclass in American Society. Berkeley and Los Angeles: University of California Press.

Jackson, Pamela Irving. 1992. "Minority Group Threat, Social Context, and Policing." In Social Threat and Social Control, edited by Allen E. Liska. Albany: State University of New York Press.

Jackson, Pamela Irving, and Leo Carroll. 1981. "Race and the War on Crime: The Sociopolitical Determinants of Municipal Police Expenditures in 90 Non-Southern Cities." American Sociological Review 46:290-305.

Jonassen, Christen. 1949. "A Reevaluation and Critique of the Logic and Some Methods of Shaw and McKay." American Sociological Review 14:608-14.

Junger, Marianne. 1989. "Discrepancies between Police and Self-Report Data for Dutch Racial Minorities." British Journal of Criminology 29:27384.

Katz, Jack. 1988. Seductions of Crime: The Sensual and Moral Attractions of Doing Evil. New York: Basic.

Katz, Michael. 1993. “The Urban 'Underclass' as a Metaphor of Social Trans- 
formation." In The "Underclass" Debate: Views from History, edited by Michael Katz. Princeton, N.J.: Princeton University Press.

$\rightarrow$ Keil, Thomas, and Gennaro Vito. 1989. "Race, Homicide Severity, and Application of the Death Penalty." Criminology 27:511-31.

Kempf-Leonard, Kimberly, Carl Pope, and William Feyerherm, eds. 1995. Minorities in Fuvenile fustice. Thousand Oaks, Calif.: Sage.

Kleck, Gary. 1981. "Racial Discrimination in Criminal Sentencing: A Critical Evaluation of the Evidence with Additional Evidence on the Death Penalty." American Sociological Review 46:783-805.

Klein, Stephen, Joan Petersilia, and Susan Turner. 1990. "Race and Imprisonment Decisions in California." Science 247:812-16.

Kornhauser, Ruth. 1978. Social Sources of Delinquency: An Appraisal of Analytic Models. Chicago: University of Chicago Press.

LaFree, Gary, Kriss Day, and Patrick O'Day. 1992. "Race and Crime in Postwar America: Determinants of African American and White Rates." Criminology 30:157-88.

Land, Kenneth, Patricia McCall, and Lawrence Cohen. 1990. "Structural Covariates of Homicide Rates: Are There Any Invariances across Time and Space?" American fournal of Sociology 95:922-63.

Langan, Patrick. 1985. "Racism on Trial: New Evidence to Explain the Racial Composition of Prisons in the United States." Fournal of Criminal Law and Criminology 76:666-83.

- 1994. "No Racism in the Justice System." Public Interest 117:48-51.

Lauritsen, Janet L., Robert J. Sampson, and John H. Laub. 1991. "The Link between Offending and Victimization among Adolescents." Criminology 29:265-92.

Liska, Allen E. 1987. "A Critical Examination of Macro Perspectives on Crime Control." Annual Review of Sociology 13:67-88.

Liska, Allen E., and Mitchell Chamlin. 1984. "Social Structure and Crime Control among Macrosocial Units." American Fournal of Sociology 90:38395.

Loeber, Rolf, and Magda Stouthamer-Loeber. 1986. "Family Factors as Correlates and Predictors of Juvenile Conduct Problems." In Crime and 7ustice: An Annual Review of Research, vol. 7, edited by Michael Tonry and Norval Morris. Chicago: University of Chicago Press.

Logan, John, and Harvey Molotch. 1987. Urban Fortunes: The Political Economy of Place. Berkeley and Los Angeles: University of California Press.

MacLean, Brian, and Dragan Milovanovic, eds. 1990. Racism, Empiricism, and Criminal fustice. Vancouver: Collective Press.

Maguire, Kathleen, and Ann Pastore, eds. 1995. Sourcebook of Criminal Fustice Statistics, 1994. Washington, D.C.: U.S. Government Printing Office, Bureau of Justice Statistics.

Mann, Coramae Richey. 1993. Unequal 7ustice: A Question of Color. Bloomington: Indiana University Press.

Marks, Jonathan. 1995. Human Biodiversity: Genes, Race, and History. Hawthorne, N.Y.: Aldine de Gruyter.

Massey, Douglas S., and Nancy Denton. 1993. American Apartheid: Segregation 
and the Making of the Underclass. Cambridge, Mass.: Harvard University Press.

Mauer, Marc. 1990. "Young Black Men and the Criminal Justice System: A Growing National Problem." Washington, D.C.: Sentencing Project.

McCord, Colin, and Harold Freeman. 1990. "Excess Mortality in Harlem." New England Fournal of Medicine 322:173-75.

McGarrell, Edmund. 1993a. "Institutional Theory and the Stability of a Conflict Model of the Incarceration Rate." Fustice Quarterly 10:7-28.

1993b. "Trends in Racial Disproportionality in Juvenile Court Processing: 1985-1989." Crime and Delinquency 39:29-48.

Meier, Robert, and Terance Miethe. 1993. "Understanding Theories of Criminal Victimization." In Crime and 7ustice: A Review of Research, vol. 17, edited by Michael Tonry. Chicago: University of Chicago Press.

Merton, Robert. 1938. "Social Structure and Anomie." American Sociological Review 3:672-82.

$\rightarrow$ Miethe, Terance, and C. Moore. 1986. "Racial Differences in Criminal Processing: The Consequences of Model Selection on Conclusions about Differential Treatment." Sociological Quarterly 27:217-37.

Miller, Walter. 1958. "Lower Class Culture as a Generating Milieu of Gang Delinquency." Journal of Social Issues 14:5-19.

Munroe, Ruth H., Robert L. Munroe, and Beatrice B. Whiting, eds. 1981. Handbook of Cross-Cultural Human Development. New York: Garland Press.

Murray, Charles. 1993. "The Coming White Underclass." Wall Street fournal (October 29), p. A14.

$\rightarrow$ Myers, Martha. 1979. "Offended Parties and Official Reactions: Victims and the Sentencing of Criminal Defendants." Sociological Quarterly 20:529-40.

1989. "Symbolic Policy and the Sentencing of Drug Offenders." Law and Society Review 23:295-315.

Myers, Martha, and Susette Talarico. 1987. The Social Contexts of Criminal Sentencing. New York: Springer-Verlag.

National Center for Health Statistics. 1995. "Advance Report of Final Mortality Statistics, 1992." Monthly Vital Statistics Report, vol. 43, no. 6, suppl. Washington, D.C.: U.S. Department of Health and Human Services.

O'Brien, Robert. 1987. "The Interracial Nature of Violent Crimes: A Reexamination." American fournal of Sociology 92:817-35.

O'Hare, William, and Brenda Curry-White. 1992. "Is There a Rural Underclass?" Population Today 20:6-8.

Paternoster, Raymond. 1984. "Prosecutorial Discretion in Requesting the Death Penalty: A Case of Victim-Based Racial Discrimination." Law and Society Review 18:437-78.

$\rightarrow$ Peeples, Faith, and Rolf Loeber. 1994. "Do Individual Factors and Neighborhood Context Explain Ethnic Differences in Juvenile Delinquency?" Journal of Quantitative Criminology 10:141-58.

Petersilia, Joan. 1983. Racial Disparities in the Criminal fustice System. Santa Monica, Calif.: RAND.

$\rightarrow-$ 1985. "Racial Disparities in the Criminal Justice System: A Summary." Crime and Delinquency 31:15-34. 
Peterson, Ruth D., and John Hagan. 1984. "Changing Conceptions of Race: Towards An Account of Anomalous Findings of Sentencing Research." American Sociological Review 49:56-70.

Piliavin, Irving, and S. Briar. 1964. "Police Encounters with Juveniles." American Fournal of Sociology 69:206-14.

Pope, Carl, and William Feyerherm. 1990. "Minority Status and Juvenile Justice Processing: An Assessment of the Research Literature" (pts. 1, 2). Criminal Fustice Abstracts (June):327-35, and (September):527-42.

Radelet, Michael. 1981. "Racial Characteristics and the Imposition of the Death Penalty." American Sociological Review 46:918-27.

Reiss, Albert J., Jr., and Jeffrey Roth, eds. 1993. Understanding and Preventing Violence: Panel of the Understanding and Control of Violent Behavior, vol. 1. Washington D.C.: National Academy Press.

Ruback, Barry, and Neil Weiner. 1993. "Introduction to Social and Cultural Aspects of Interpersonal Violent Behaviors." Violence and Victims 8:193-98.

Sampson, Robert J. 1984. "Group Size, Heterogeneity, and Intergroup Conflict: A Test of Blau's Inequality and Heterogeneity." Social Forces 62:618-39. 1986. "Effects of Socioeconomic Context on Official Reaction to Juvenile Delinquency." American Sociological Review 51:876-85.

- 1987. "Urban Black Violence: The Effect of Male Joblessness and Family Disruption." American fournal of Sociology 93:348-82.

Sampson, Robert J., and W. Byron Groves. 1989. "Community Structure and Crime: Testing Social-Disorganization Theory." American fournal of Sociology 94:774-802.

Sampson, Robert J., and John H. Laub. 1992. "Crime and Deviance in the Life Course." Annual Review of Sociology 18:63-84.

- 1993a. "Structural Variations in Juvenile Court Processing: Inequality, the Underclass, and Social Control." Law and Society Review 27:285311.

1993b. Crime in the Making: Patbways and Turning Points through Life. Cambridge, Mass.: Harvard University Press.

Sampson, Robert J., and Janet L. Lauritsen. 1994. "Violent Victimization and Offending: Individual, Situational, and Community-Level Risk Factors." In Understanding and Preventing Violence: Social Influences, vol. 3, edited by Albert J. Reiss, Jr., and Jeffrey Roth. Washington, D.C.: National Academy Press.

Sampson, Robert J., and William Julius Wilson. 1995. "Toward a Theory of Race, Crime, and Urban Inequality." In Crime and Inequality, edited by John Hagan and Ruth Peterson. Stanford, Calif.: Stanford University Press.

Sellin, Thorsten. 1935. "Race Prejudice in the Administration of Justice." American fournal of Sociology 41:212-17.

Shaw, Clifford, and Henry McKay. 1969. Juvenile Delinquency and Urban Areas. Rev. ed. Chicago: University of Chicago Press. (Originally published 1942.)

—. 1949. "Rejoinder." American Sociological Review 14:614-17.

Simon, Jonathan. 1993. Poor Discipline: Parole and the Social Control of the Underclass, 1890-1990. Chicago: University of Chicago Press. 
Singer, Simon. 1981. "Homogeneous Victim-Offender Populations: A Review and Some Research Implications." Journal of Criminal Law and Criminology 72:779-88.

Skogan, Wesley. 1981. "Assessing the Behavioral Context of Victimization." Fournal of Criminal Law and Criminology 72:727-42.

- 1986. "Fear of Crime and Neighborhood Change." In Communities and Crime, edited by Albert J. Reiss, Jr., and Michael Tonry. Vol. 8 of Crime and Fustice: A Review of Research, edited by Michael Tonry and Norval Morris. Chicago: University of Chicago Press.

Smith, Douglas A. 1986. "The Neighborhood Context of Police Behavior." In Communities and Crime, edited by Albert J. Reiss, Jr., and Michael Tonry. Vol. 8 of Crime and Fustice: A Review of Research, edited by Michael Tonry and Norval Morris. Chicago: University of Chicago Press.

Smith, Pheny. 1993. "Felony Defendants in Large Urban Counties, 1990." Washington, D.C.: Bureau of Justice Statistics.

Snyder, Howard. 1990. "Growth in Minority Detentions Attributed to Drug Law Violators." Washington, D.C.: Office of Juvenile Justice and Delinquency Prevention.

- 1992. "Arrests of Youth 1990." Washington, D.C.: Office of Juvenile Justice and Delinquency Prevention.

Spohn, Cassia, John Gruhl, and Susan Welch. 1987. "The Impact of the Ethnicity and Gender of Defendants on the Decision to Reject or Dismiss Felony Charges." Criminology 25:175-92.

Sullivan, Mercer. 1989. Getting Paid: Youth Crime and Work in the Inner City. Ithaca, N.Y.: Cornell University Press.

Tienda, Marta. 1991. "Poor People and Poor Places: Deciphering Neighborhood Effects on Poverty Outcomes." In Macro-Micro Linkages in Sociology, edited by Joan Huber. Newbury, Calif.: Sage.

Tittle, Charles R. 1994. "The Theoretical Bases for Inequality in Formal Social Control." In Inequality, Crime, and Social Control, edited by George Bridges and Martha Myers. Boulder, Colo.: Westview.

Tittle, Charles R., and Debra A. Curran. 1988. "Contingencies for Dispositional Disparities in Juvenile Justice." Social Forces 67:23-58.

Tonry, Michael. 1995. Malign Neglect: Race, Crime, and Punishment in America. New York: Oxford University Press.

Turk, Austin T. 1969. Criminality and the Legal Order. Chicago: Rand McNally.

Uniform Crime Reports. 1980. Crime in the United States. Washington, D.C.: U.S. Government Printing Office.

- 1985. Crime in the United States. Washington, D.C.: U.S. Government Printing Office.

U.S. Bureau of Census. 1993. Statistical Abstract of the United States: 1993. 113 th ed. Washington, D.C.: U.S. Government Printing Office.

U. S. Department of Justice. 1988. Report to the Nation on Crime and Fustice, 2d ed. Washington, D.C.: U.S. Government Printing Office, March.

1990. Hispanic Victims, Special Report. Washington, D.C.: U.S. Government Printing Office. 
1993a. Crime in the United States, 1992. Washington, D.C.: U.S. Government Printing Office.

1993b. Age-Specific Arrest Rates and Race-Specific Arrest Rates for Selected Offenses, 1965-1992. Washington, D.C.: U.S. Government Printing Office.

- 1994a. Criminal Victimization in the United States, 1973-1992 Trends. A National Crime Victimization Survey Report. Washington, D.C.: U.S. Government Printing Office, June.

- 1994b. Criminal Victimization in the United States, 1992. Washington, D.C.: U.S. Government Printing Office.

- 1994c. Prisoners in 1993. Bureau of Justice Statistics Bulletin. Washington, D.C.: U.S. Government Printing Office.

-1995. Correctional Populations in the United States, 1993. Executive Summary. Washington, D.C.: U.S. Government Printing Office.

$\rightarrow$ Wilbanks, William. 1985. "Is Violent Crime Intraracial?" Crime and Delinquency 31:117-28.

- 1986. "Criminal Homicide Offenders in the U.S.: Black vs. White." In Homicide among Black Americans, edited by Darnell Hawkins. Lanham, Md.: University Press of America.

- 1987. The Myth of a Racist Criminal Fustice System. Monterey, Calif.: Brooks/Cole.

Williams, Robin, Jr. 1994. "The Sociology of Ethnic Conflicts: Comparative International Perspectives." Annual Review of Sociology 20:49-79.

Wilson, James Q., and Richard Herrnstein. 1985. Crime and Human Nature. New York: Simon \& Schuster.

Wilson, William Julius. 1987. The Truly Disadvantaged: The Inner City, the Underclass, and Public Policy. Chicago: University of Chicago Press.

Wilson, William Julius, R. Aponte, J. Kirschenman, and Loic Wacquant. 1988. "The Ghetto Underclass and the Changing Structure of American Poverty." In Quiet Riots: Race and Poverty in the United States, edited by F. Harris and R. W. Wilkins. New York: Pantheon.

Wolfgang, Marvin. 1958. Patterns in Criminal Homicide. New York: Wiley.

Wolfgang, Marvin, and Franco Ferracuti. 1967. The Subculture of Violence. London: Tavistock.

$\rightarrow$ Wordes, Madeline, Timothy Bynum, and Charles Corley. 1994. "Locking up Youth: The Impact of Race on Detention Decisions." Journal of Research in Crime and Delinquency 31:149-65.

$\rightarrow$ Zatz, Marjorie. 1984. "Race, Ethnicity and Determinate Sentencing: A New Dimension to an Old Controversy." Criminology 22:147-71.

$\rightarrow-$ 1987. "The Changing Forms of Racial/Ethnic Biases in Sentencing." Journal of Research in Crime and Delinquency 24:69-92. 